\title{
The impact of river regulation in the Tigris and Euphrates on the Arvandroud Estuary
}

Ali Torabi Haghighi University of Oulu, Finland

Mojtaba Sadegh Boise State University, USA

Joy Bhattacharjee University of Oulu, Finland

Mehmet Emin Sönmez Gaziantep University, Turkey

Mojtaba Noury Iran Water Resources Management Company, Ministry of Energy, Tehran,

Iran

Nese Yilmaz Istanbul University, Turkey

Roohollah Noori University of Tehran, Iran

Bjørn Kløve University of Oulu, Finland

\section{ABSTRACT}

The Arvandroud river (also known as Shatt-al-Arab) and its estuary have been degraded due to changing river flow regime in the Tigris and Euphrates rivers. This study assessed changes in flow from the major rivers and the impacts on the estuary. To assess the river flow changes, three major flow regime attributes were computed: timing (TIF), magnitude (MIF), and variability (VIF). By combining these indices, the total flow regime impact factor (IF) was scaled between 0 and 1 , and classified into five groups: Low $(0.80<\mathrm{IF}<1.0)$, Incipient $(0.60<\mathrm{IF}<0.80)$, Moderate $(0.40<\mathrm{IF}<0.60)$, Severe $(0.2<\mathrm{IF}<0.40)$, and Drastic $(0.0<\mathrm{IF}<0.20)$. Flow regime impact maps were then created for 1941-1955, 1960-1970, 1975-1984, and 1990-2000. These revealed that, over time, the impact has extended along the basin from downstream to upstream, with a significant flow regime change from 1941-1955 to 1990-2000 in the Tigris, Euphrates, and Arvandroud. Analysis of remote sensing data revealed that the change in the flow regime has led to land degradation in the Arvandroud estuary during the past 46 years (1972-2018). In addition, the impact of Iran- Iraq war (based on degradation of vegetation cover between 1985-1988) is 5.1 times of mean rate of change during 1972-2018. This study thus contributes new information on estuaries and the impact of upstream land and water use change.

Keywords: River regime changes; Dams; Remote sensing; Impact assessment; Land degradation

\section{Introduction}

In several large river systems, land and water management practices have led to major changes in river flow (e.g. (Radinger et al. 2018, Torabi Haghighi and Kløve 2017, Fazel et al. 2017, Eng et al. 2013, Nilsson et al. 2005). Anthropogenic interference e.g. land use and cover change, river modification beside of climate change are influence on major characteristics of flow regime in river (Ashraf et al. 2018, Hekmatzadeh et al. 2020, Mustonen et al. 2016, Pirnia et al. 2019, Torabi Haghighi et al. 2019, Yaraghi et al. 2019). Managing large rivers is especially challenging as they are transboundary, with different upstream and downstream water management interests. In many river basins, e.g., that of the Zambezi (Petersen-Perlman 2016), the Mekong (Hirsch 2016, Sneddon and Fox 2006), and the Indus (Akhter 2015), headwater regulation and increased water use have altered downstream flow and sediment regime, with effects on ecosystems, navigation, fisheries, and agriculture. Estuaries are particularly important in this regard, due to their many ecosystem services and high socio-economic value. Furthermore, sea level rise and other changes in coastal water resources are adding to existing pressures on estuaries (Lotze et al., 2006).

The Tigris and Euphrates are important transboundary rivers in the Middle East that drain water from Turkey, Iraq, Syria, Iran, Jordan, and Saudi Arabia to the Persian Gulf. The competing interests of Turkey, Syria, and Iraq have led to conflicts on how the water should be shared (Al-Ansari, N.A., Sherwany, G. and Knutsson, S. 2014, Biedler 2004, Rowley 1993, Sofer 1999, Yetim 2002, Yilmaz 2003). Construction of more than 140 dams (FAO 2009) in the Tigris-Euphrates basin has resulted in significant flow alteration, with less water for meeting the water demand of downstream and aquatic ecosystems, including the coastal zone, 
estuaries, and wetlands. The flow regime in the Arvandroud estuary (below the confluence of the Tigris and Euphrates) is severely affected by upstream developments, but poorly documented to date.

The Arvandroud estuarine zone covers an area of approximately $10-20 \times 10^{3} \mathrm{~km}^{2}$ and encompasses wetlands, sandbars, marshes, ponds, ox-bow lakes, and tidal flats (Patiris et al. 2016). In recent years, river regulation and land drainage have led to degraded water quality (Ghandehari et al. 2007, Al Bomola 2011), salt water intrusion (Etemad Shahidi et al., 2011), reduced ecological status (Partow 2001, Al-Mutairi et al. 2014, Al-Yamani 2008), decreased fisheries (Richardson and Hussain 2006), drying of marshes and wetlands (Richardson and Hussain 2006, Fuladavand and Sayyad 2015), and desertification and increasing dust storms (Keramat et al. 2011, Zarasvandi et al. 2011, Hamidi et al. 2013, Cao et al. 2015). Furthermore, in addition to the significant anthropogenic pressures, during the past 30 years the region has suffered from the impacts of two major wars.

The main objective of this study was to assess and quantify the hydrological impact of intra-annual river regime alteration at Arvandroud and some key points in the Tigris and Euphrates rivers. Due to limited access to recent hydrological data, remote sensing images were analysed for addressing possible hydrological impact on Arvandroud estuarine in recent years. The aim was to contribute to existing literature on upstream regulation impacts on estuaries, which contains descriptions of other major river basins worldwide. In the Arvandroud area, water scarcity is a key issue, along with river regulation, making this case different from those reported previously. Additionally, the region is politically sensitive, including transboundary water policy.

\section{Material and methods}

\subsection{Study area}

The Arvandroud is a short transboundary river located after the confluence of the Tigris and Euphrates near the city of Qurnah in Iraq, about $110 \mathrm{~km}$ northwest of Abadan city in Iran. The river flows to the Persian Gulf after passing the Port of Basra in Iraq and joining the Karun river near the city of Khorramshahr in Iran (Fig. 1). Before discharging into the Persian Gulf, the Arvandroud varies between 270-2500 $\mathrm{m}$ in width and 9-15 $\mathrm{m}$ in depth, which means that it is navigable. It supports marine habitats along the northwest coast of the Persian Gulf and in the Mesopotamian marshes (UN-ESCWA et al. 2013). Limited access to hydrological data is one of the major challenges in research on this basin (Kavvas et al. 2011).

In this study, the variation in total flow at the last station on each of the two major tributaries (Kut on Tigris and Hit on Euphrates) was used to calculate the inflow to the Arvandroud. In addition, to better understand the impact of river regulation on the flow regime in the two main tributaries and their headwaters, and to evaluate the hydrological impact on river flow, we used data from a set of 21 gauging stations widely distributed along the rivers at points of major development (e.g., dams) in different parts of basin (Fig. 1 and Table 1). All flow regime alteration has been estimated based on monthly flow.

The main area of riverine nearby the estuarine has been covered by date palms trees. The date palms are the major economic source of inhabitants in this area and irrigated by many diverted channels from the Arvandroud. Based on the length of irrigation channel around the Arvandroud in both sides, we made a polygon of vulnerable area for evaluating the possible impact of river regime alteration on vegetation cover and mainly date palms (Fig. 1b). Inside of the polygon we select 9 areas which are covered by dense vegetation to better address the change in land cover (Fig. 1b).

\subsubsection{The Euphrates and its flow regime}

The Euphrates river, with a basin area of $440,000 \mathrm{~km}^{2}$, is the longest river $(2786 \mathrm{~km})$ in western Asia, with three main riparian countries (Iraq 47\%, Syria 22\%, Turkey 28\%). The Euphrates river basin also extends into Saudi Arabia (2.97\%) and Jordan (0.03\%) (Fig. 1). The Karasu and Murat rivers, the two major tributaries of the Euphrates, originate in eastern and western Turkey, respectively. Other tributaries are the Sajur, Khabour, and Balikh, which originate in Syria. Rainfall over the course of the Euphrates varies from $1000 \mathrm{~mm}$ in its headwaters (cold Mediterranean climate in Turkey) to $150 \mathrm{~mm}$ in the Syrian territory and $75 \mathrm{~mm}$ in southern 
Iraq (hot, dry climate) (Fig. 2a). The estimated area of irrigated land fed by Euphrates water is 2.3 million ha (UN-ESCWA et al. 2013).

The monthly flow regime during 1941-1955 at Hit gauging station (with an upstream watershed area of $264,100 \mathrm{~km}^{2}$ ) on the Euphrates was used to estimate the natural flow (pre-impact flow in Fig. 3a-d). There is an additional gauging station on the Euphrates below the Hindiya barrage (upstream watershed area 274,100 $\mathrm{km}^{2}$; (Saleh 2010), but it was not considered suitable for natural flow analysis as it has been impacted by the barrage since 1911. As a result, while an additional area of $10,000 \mathrm{~km}^{2}$ (mid-basin) contributes to flow at Hindiya station, the actual flow generated in this additional area is negligible (less than $0.5 \%$ of total flow).

To illustrate this, based on available data and the layout of the basin, the Euphrates basin was divided into three sub-basins, namely the upper Keban dam in Turkey $\left(63,875 \mathrm{~km}^{2}\right)$, mid-basin between Keban dam and Tabaqa dam in Syria $\left(57,125 \mathrm{~km}^{2}\right)$, and the rest of the basin between Tabaqa dam and above Hit station in Iraq $\left(143,100 \mathrm{~km}^{2}\right)$. The influence of the basin section between Hit station and Hindiya station was considered minimal, due to the predominating hot desert climate (climate type BWh according to the Köppen classification system (Peel et al. 2007) and lack of precipitation (Fig. 2a-c). Mean annual (1931-1950) specific discharge (flow/basin area) for the upper Keban dam, Keban dam to Tabaqa dam, and Tabaqa dam to Hit station sub-basins was 9.73, 3.59, and $0.42 \mathrm{~L} \mathrm{~s}^{-1} \mathrm{~km}^{-2}$, respectively, due to different climate and precipitation conditions (Fig. 2d). The contribution of the sub-basins above Tabaqa dam (121,000 km²; (UNESCO 2013)) and of the basin above Keban dam was around $95 \%$ and $70 \%$, respectively, of flow at Hit station (combined basin 264,100 km²; (Saleh 2010)).

The flow regime of the Euphrates at Hit 1931-1950 was assumed to be natural flow, since at that time the river was not regulated by any important reservoir upstream of this station. The contribution of basin area to river flow decreases from the northern part of the basin (headwater tributaries; Fig. 2d) towards the south, with only $5 \%$ of the flow rate at Hit being generated by the sub-basin between Tabaqa dam and Hit station. With a simplifying assumption of linearity for the system and considering that an area of roughly $143,100 \mathrm{~km}^{2}$ between Tabaqa and Hit contributes 5\% to the flow, one can readily calculate the contribution to river flow of the $10,000 \mathrm{~km}^{2}$ basin area between Hit and Hindiya as: $5 \% \times \frac{10,000}{143,100}=0.35 \%$. Therefore, the area between Hit and Hindiya only contributes around $0.35 \%$ to the flow and the flow rate at Hit (1940-1955) can confidently be considered the pre-impact flow of the Euphrates before discharging to the Arvandroud. To evaluate flow regime alteration in headwaters of the Euphrates, we examined the monthly flow change in its two major tributaries, the Karasu and Murat (Figs. 4a and 4b).

\subsubsection{The Tigris and its flow regime}

The Tigris river, which is $1800 \mathrm{~km}$ long and has a basin area of approximately $221,000 \mathrm{~km}^{2}$, is the second longest river in western Asia. The Tigris basin expands over four riparian countries (Iraq 56.1\%, Turkey $24.5 \%$, Iran $19 \%$, Syria $0.4 \%$ ). The river Tigris is regulated by several storage and diversion dam projects in Iraq and Turkey, to irrigate over 4.5 million ha of farmland inside the basin and around 150,000 ha outside it. The climate varies from semi-humid $(800 \mathrm{~mm}$ annual rainfall) in the north to semi-arid (150 mm annual rainfall) in the south (Fig. 2). The Tigris originates in the Armenian Highlands in eastern Turkey and is fed by many tributaries, such as the Greater Zab (basin area of 25,810 $\mathrm{km}^{2}$ ), Lesser Zab $\left(21,475 \mathrm{~km}^{2}\right.$ ), Al-Adhaim $\left(13,000 \mathrm{~km}^{2}\right)$, and Diyala $\left(31,896 \mathrm{~km}^{2}\right)$ located in the Zagros Mountains in Iran, Iraq, and Turkey (UNESCWA et al. 2013).

The Kut barrage is the last station on the Tigris with available flow data (before it discharges to the Arvandroud). The Kut barrage diverts a portion of Tigris flow for irrigation purposes through the Gharraf Canal. The pre-impact flow in the Tigris was estimated by adding the Gharraf Canal flow to available flow data at the Kut gauging station ('Pre-impact' in Figs. 3e-h). To evaluate flow regime alteration in headwaters of the Tigris, we examined the monthly flow change at two points on the main corridor of the Tigris, Diyarbakir, Cizre (Figs. 4c and 4d), and one of major tributaries of Tigris, the Great Zab at Bekhem (Fig. 4i). In addition, we considered two important points on the Tigris, at Mosul and Baghdad, to evaluate the impact of Mosul dam and Samara barrage (Figs. 4e and 4f).

To estimate the flow regime alteration due to Samara barrage on the Tigris, gauging stations above (Beiji) and below (Baghdad) Samara dam were considered. The Diyala (also known as Sirwan) river is a 
tributary that joins the Tigris between Beiji and Baghdad stations, whereas water extraction is minimal between the two stations. To compare the two stations, we adjusted the flow rate at Baghdad by removing the contribution of the Diyala. After this adjustment, the difference in mean monthly flow between Baghdad and Beiji stations before construction of Samarra dam (1940-1955) was minimal ('Pre-impact' and 'Post-impact1' in Fig. 4f), confirming the validity of our decision to compare these two stations as pre- and post-impact.

\subsubsection{Karkheh and Karun}

The Karun is the largest river (in terms of discharge) in Iran and the Karkheh is the longest. Both rivers are fed by snowmelt and rainfall and originate in the Zagros Mountains in western Iran. These rivers run entirely inside Iran's territory and are considered an internal water of Iran. Historically, Karun flow was not part of the Arvandroud water system, since before 1765 the river discharged to the Persian Gulf through many channels and rivers such as Bahmanshir river, Nahre Ghadimi, and Nahre Koor. In 1765, the Karun was connected to the Arvandroud artificially with a canal for navigation purposes (UN-ESCWA et al. 2013). The Karkheh feeds the Hooralazim wetland, with excess water during high flow years discharging to the Arvandroud system. Although these two rivers are not main contributors to the impact on the Arvandroud, river regime alteration (at Ahvaz and Hamidieh) was taken into account in this study (Figs. 4g and 4h).

\subsubsection{Flow regime at Arvandroud}

Flow measurement in the Arvandroud is uncertain due to inflow of fresh water from upstream and tidal effects from the Persian Gulf. The tide in Arvandroud is classified as semidiurnal, reaching an average rise of $2.6 \mathrm{~m}$ at the mouth of the river at the Persian Gulf. The tide affects the upstream river by an average of $1.4 \mathrm{~m}$ at Abadan city (about $74 \mathrm{~km}$ from the river mouth) and continues upstream (Zahed et al. 2008, Etemad Shahidi et al. 2011). Due to unrealistic flow values, the last existing gauging station (Khosoro-Abad) was shut down in 1994. As mentioned, to resolve this lack of direct measurements we used the sum of discharge data for the two last available points on the Tigris and Euphrates. Although there is a mid-basin between these two stations and the river confluence point at Qurnah (Figs. 1 and 2a), in comparison with upstream areas the contribution of this area to monthly flow is negligible (this is explained for the Euphrates in section 3.1). Due to the low amount of annual rainfall (less than $100 \mathrm{~mm}$; Fig. 2a) and high mean annual temperature (about $25{ }^{\circ} \mathrm{C}$; Fig. $2 \mathrm{~b}$ ), the climate in most of this area is classified as hot desert (BWh according to the Köppen climate classification system; Fig. 2c). Thus, the amount of flow generated in the area is insignificant (Fig. 2d). The total sum of pre-impact flow (1941-1955) at Hit station on the Euphrates and Kut station on the Tigris was considered natural inflow to the Arvandroud river system (Pre-impact in Figs. 3i-1). The sum of flow between Kut and the Hindiya barrage during 1941-1955, 1960-1970, 1974-1984, and 1990-1999 was considered altered (post-impact) flow (Figs. 3i-1).

\subsection{River regime impact}

Existing methodology (Torabi Haghighi et al. 2014) was used to quantify river regime impacts by combining three major attributes of flow regime (magnitude, timing, and variation in monthly flow) through comparison of intra-annual flow regime pre- and post- impact. This method is presented in Fig. 5 and quantifies the total impact on flow regime as:

$$
\mathrm{RI}=\mathrm{MIF} \times(\mathrm{TIF}+\mathrm{VIF})
$$

where RI is river impact; MIF is a flow magnitude impact factor that is a function of water consumption and quantifies change in flow magnitude before and after development (Fig. 5b); TIF is a timing impact factor that considers changes in the timing of maximum, minimum, and median discharge cumulative density function (Fig. 5c), and VIF is an intra-annual flow variability impact factor that indicates how a natural flow regime approaches more uniform flow after dam construction (Fig. 5d). These three impact factors can be quantify as follow: 
The MIF can be calculated as:

$$
\mathrm{MIF}_{1}=\mathrm{AOF} / \mathrm{AIF} \quad \text { or } \quad \mathrm{MIF}_{2}=\mathrm{AF}_{\text {Post }} / \mathrm{AF}_{\text {Pre }}
$$

In Eq. (1), AOF and AIF are the annual outflow/inflow from/to the dam $\left(\mathrm{m}^{3} \mathrm{or} \mathrm{m}^{3} \mathrm{~s}^{-1}\right)$, respectively, $\mathrm{AF}_{\text {Post }}$ is the annual outflow from the dam after dam construction, and AFPre is the annual flow rate with no dam.

The VIF is calculated as Eq. (2):

$$
\mathrm{VIF}=\left(50-\frac{\left|\mathrm{IRR}_{\text {Pre }}-\mathrm{IRR}_{\text {Post }}\right|}{\mathrm{IRR}_{\text {Pre }}} \times 50\right) \times 100
$$

In the above equation, the IRR is the river regime index introduced by Haghighi and Kløve (2013). The IRR is dependent on the annual flow hydrograph fluctuation varied between 0 (uniform flow) and 1200 (strongly seasonal flow regime). A calculator tool for the RRI can be found in the Supplementary Material in Haghighi and Kløve (2013). Also, the subscribes "Pre" and "Pos" are indicators of the river condition under pre- and post-construction of dam. By considering these, the VIF is varied between 0 and 0.5 .

The TIF considers timing changes in minimum, maximum, and timing of the fifty percent value of the flow cumulative density function (cdf50) and calculates as:

$$
\mathrm{TIF}=\left(50-0.274 \times\left(\frac{\left|\mathrm{DT}_{\text {max }}\right|+\left|\mathrm{DT}_{\text {min }}\right|+\left|\mathrm{DT}_{\text {median }}\right|}{3}\right)\right) / 100
$$

where $\mathrm{DT}_{\max }, \mathrm{DT}_{\min }$, and $\mathrm{DT}_{\text {median }}$ are the time shift in monthly maximum discharge, minimum discharge, and cdf50 timing value, respectively. The VIF is varied between 0 and 0.5 .

Based on the RI index (which varies between a maximum impact of 0 and a minimum impact of 1 ), the river regime impact can be classified into one of five groups: Low: RI $>0.8$, Incipient: $0.6<\mathrm{RI}<0.8$, Moderate: $0.4<\mathrm{RI}<0.6$, Severe: $0.2<\mathrm{RI}<0.4$, and Dramatic: $0<\mathrm{RI}<0.2$. This classification is subjective and case-sensitive but is deemed appropriate for most river systems by Torabi Haghighi et al. (2014).

Here we performed the analysis using either a temporal or spatial approach to quantify the river regime impact at the point of interest. In temporal analysis, only the date of impact (e.g., dam construction) is considered. The available time series of data at any point is divided into two parts, pre-impact and post-impact, and the river impact (RI) is computed by contrasting the mean monthly flow in the pre-impact and post-impact periods (e.g., the impact of Mosul dam construction was evaluated using this approach) (Fig. 4e). The disadvantage of this approach lies in the impact of climate variation on the computed index, specifically when one period (pre- or post-) belongs to a dry period and the other belongs to a wet period. In this case, the impact of climate variability confounds the impact of the dam. However, this error decreases as the length of the data series increases.

In spatial analysis, mean monthly flow at two stations (in the same period) above and below a point of interest are considered pre- and post- impact time series data and used to compute the RI index. For example, in the present case the impact of Samara dam on the Tigris was evaluated through comparison of the flow of the Tigris at Beiji and Baghdad stations (Fig. 4f). The drawback of this approach is the effect of added flow from sub-basins between the two selected stations on flow rate at the lower station. The error in the impact index grows as the distance between the two stations increases and the area of mid-basin expands. This error can potentially be compensated for if the additional flow stemming from the mid-basin is gauged (e.g., by measuring the discharge of tributaries that join the major river between the two selected stations). However, this error is minimal in dry climate areas such as southern part of the Tigris-Euphrates basin, where annual rainfall is very low. Spatial or temporal analysis was used for all stations, rivers, and tributaries along the basin except for the Arvandroud river, in which the flow measurement is extremely complicated due to different hydraulic forces acting upon this river.

\subsection{Land use-land cover change analysis}

To assess the impact of flow regime alteration on lowland area, we assessed land use-land cover (LULC) change based on the available Landsat images for Arvandroud estuary. We considered Landsat MSS images (01 August 1972, 16 August 1978 and 22 July 1985); Landsat TM image (09 August 1988); Landsat ETM+ image (17 August 2002); and Landsat OLI/TIRS (21 August 2018) for the analysis. The images are downloaded from USGS Earth Resources Observation Systems data center. The analyzed images were selected from similar month, to avoid seasonal effects on vegetation. Less than $10 \%$ cloud cover was another criterion to select those images. For Image processing and classification purpose, we used maximum 
likelihood (ML) procedure in ArcGIS software. Based on the topography of the region, four types of land use were identified: 1) Water bodies, including deep and shallow water; 2) bare areas, including sandy flats and areas without plants; 3) areas with low vegetation density; and 4) areas with high vegetation density, including wetlands and irrigated areas. In addition, we considered normalized difference vegetation index (NDVI) to detect the density of green vegetation:

$$
N D V I=\frac{B_{N I R}-B_{R e d}}{B_{N I R}+B_{R e d}}
$$

where $\mathrm{B}_{\text {Green, }} \mathrm{B}_{\text {red }}$ and $\mathrm{B}_{\mathrm{NIR}}$ are top-of-atmosphere (TOA) reflectance or surface reflectance in the green, red, and near-infrared band, respectively.

A time series of NDVI value (1984-2018) for nine selected areas (Fig. 1b) has been acquired from https://app.climateengine.org/ (Climate Engine, 2016).The NDVI approach can be used to distinguish changes in different vegetation covers (Hamel et al. 2009, Torabi Haghighi, et al. 2018). The NDVI values has been standardized by Z-Score method to assess the temporal variation of NDVI (Abdi, 2007).

$$
Z_{\text {Score }}=\frac{N D V I-\overline{N D V I}}{S_{N D V I}}
$$

where $\overline{N D V I}$ is the mean value of NDVIs and $S_{N D V I}$ is the standard deviation of the NDVIs.

\section{Results and discussion}

\subsection{Water use trends and water management history}

Historically, Iraq was the first country to control water and develop agriculture in the Tigris-Euphrates basin, when it constructed two barrages, Hindiya (1911) and Kut (1934), on the Euphrates and Tigris, respectively (FAO 2009). River regulation has expanded exponentially since then. In the 1960s, Turkey and Syria initiated construction of Keban and Tabaqa (Assad reservoir) dams, respectively. In the 1980s, Turkey launched the GAP (Southeastern Anatolia Project), which included construction of 22 dams and 19 hydropower facilities on both rivers to supply water for 1.7 million hectares irrigation and generate 21 billion KWH/ year (Biedler 2004, FAO 2009). Also, the main purpose for major reservoirs in Iraq and Syria rely on developing irrigation and electricity (main purposes of major dams were presented in Table S2 in supplementary material).

A dataset gathered in 2010 for the entire river system shows that Turkey has the highest total dam capacity (about $150 \mathrm{~km}^{3}$ ), followed by Iraq, Iran, and Syria (Fig. 6a). In the history of Euphrates regulation, 1970-1975 and 1984-1992 are important periods. In the first period, Keban dam (Turkey, 1975, volume 31 $\mathrm{km}^{3}$ ) and Tabaqa dam (Syria, 1973, volume $11.2 \mathrm{~km}^{3}$ ) were constructed (combined volume $42.2 \mathrm{~km}^{3}$ ), while in the second period Haditha dam (Iraq, 1984, volume $8.2 \mathrm{~km}^{3}$ ), Karakya dam (Turkey, 1987, volume 9.5 $\mathrm{km}^{3}$ ) and Ataturk dam (Turkey, 1992, volume $48.7 \mathrm{~km}^{3}$ ) were constructed (combined volume $\left.66.6 \mathrm{~km}^{3}\right)($ Fig. $6 b)$.

The major change in the Tigris occurred in 1954, when Samarra dam diverted a great portion of river's flow to Lake Tharthar (72.8 $\mathrm{km}^{3}$ ) (Fig. 6c). In both the Tigris and Euphrates, long-term mean annual flow is lower than the reservoir capacities (Figs. 6b and 6c). Before 1977, the Karun river was regulated only by two dams (Dez, 1962, volume $2.86 \mathrm{~km}^{3}$; Karun1, 1976, volume $3.14 \mathrm{~km}^{3}$ ). Further construction on the Karun and Karkheh rivers (roughly $10 \mathrm{~km}^{3}$ ) was implemented after 1992 (Fig. 4d). Based on the FAO database (FAO 2009), the chronology of key developments and list of major dams are presented in Tables S1 and S2, respectively. Based on the available data and also the chronology of key developments, we selected four periods to assess flow regime alteration in the Arvandroud estuary: 1941-1955, 1960-1970, 1974-1984, and 1990-2000. 


\subsection{Flow regime alteration in the Euphrates}

After construction of dams in the river basin, the flow regime of the Euphrates has changed considerably from upstream to downstream. The river impact (RI, Eq. (1)) change at the Hindiya gauge (Figs. 3a-d), the lowest Euphrates flow monitoring point, showed a significant regime change between 1941-1955, 1960-1970, 19741984, and 1990-2000, with RI of 0.64, 0.63, 0.34, and 0.17, respectively (Fig. 5m). Thus Euphrates river flow regime impact has changed from 'Incipient' during 1940-1955 to 'Drastic' during 1990-2000 (Figs. 3a-d and 7a). Of the four selected periods, the smallest change occurred between the two first. A change in the flow regime from 'Incipient' to 'Severe' occurred during 1974-1984, when two considerable reservoirs (Keban, 31 $\mathrm{km}^{3}$, Tabaqa $11.2 \mathrm{~km}^{3}$ ) were constructed (Figs. 1 and 6c). More recent developments, including construction of dams such as Ataturk (1992, $\left.48.7 \mathrm{~km}^{3}\right)$, Karakaya $\left(1992,9.6 \mathrm{~km}^{3}\right)$, and Haditha $\left(1984,8.2 \mathrm{~km}^{3}\right)$, had a 'Drastic' impact on river flow in lower parts of the Euphrates river basin and the Arvandroud estuarine zone during 1990-99 (Figs. 3d and 7a).

The impact of river regulation is evident in the RI factor at Hindiya barrage, which changed from 0.64 ('Incipient') to 0.51 ('Moderate') from 1940-1955 to 1971-1993 (Fig. 4e), while the RI in 1960-1970 was still 0.64 ('Incipient'). The initial dam construction is not evident in the RI factor, as the dam had a low storage capacity and only diverted a fraction of the flow for irrigation. Further construction of numerous dams in Iraq, Turkey, and Syria in 1971-1993 has had a clear effect on river flow at Hindiya station. The change in flow rate at Hit station between the periods 1950-1970 and 1975-1984 shows that Keban (1973) and Tabaqa (1975) dams had a 'Moderate' effect on Euphrates flow.

The impact of river regime change in headwaters and lower part of Euphrates is shown in Figs. 7a and 7b. Water management in all three countries (Turkey, Iraq, and Syria) has contributed to significant flow regime alteration in lower parts of the Euphrates basin. Due to lack of available up-to-date flow data for around the border of Turkey-Syria and Syria-Iraq, assessing the exact contribution of each country is complicated. However, based on dam capacity, Turkey has played a major role in river regime alteration in lowland areas.

To assess the potential role of climate change on the Euphrates, the RI for the Murat and Karasu rivers at Elazı̆g-Palu $\left(25447 \mathrm{~km}^{2}\right)$ and Mus-Bingöl $\left(2098.4 \mathrm{~km}^{2}\right)$ was computed (Figs. 4a, b and $7 \mathrm{~b}$ ). These two stations are located in the unregulated part of the Euphrates, so a change in flow regime would reflect natural variations or climate change impacts. Based on Eq. 1, the impact of river flow alteration between 1961-1979 and 1991-2006 was classified as 'Low' (Fig. 7b), which indicates a minor impact on runoff due to climate change.

\subsection{Flow regime alteration in the Tigris}

The RI for the Tigris river at the last station before joining the Euphrates to form the Arvandroud was calculated to be $0.82,0.53,0.48$, and 0.12 for 1940-1955, 1960-1970, 1974-1984, and 1990-2000, respectively (Figs. 3e-h and 7a). This confirmed the significant change in impact from 'Low' to 'Drastic' on delivered flow regime to lower parts of the Tigris river (follow squares sign in Fig. 7a).

The Samarra-Tharthar system (1954-1956) is the largest diversion system on the main corridor of the Tigris. To evaluate the impact of this water regulation system, mean monthly flow at Beiji, upstream of the Samarra barrage, was compared with that at Baghdad gauge station, downstream of the barrage (Fig. 4f). Total impact on flow regime between these stations before this development was classified as 'Low' based on RI (Figs. 4f and 7b). The impact on timing and variability of flow was negligible (0.96), as there is no reservoir between two stations, so the river flow regime did not show any change in TIF and VIF (vertical axis in Fig. $7 b$ ). Thus the computed total impact derived largely from the change in the magnitude of flow (MIF). The impact of Samara dam was estimated based on comparison of these two stations in the period 1961-1981 (before Mosul dam, Iraq, 1983, $12.5 \mathrm{~km}^{3}$; 'Post2' in Fig. 4f), when the impact was classified as 'Incipient' (Figs. 4f and 7b). Due to low storage capacity of the barrage during this period, the majority of flow during the high flow season (December-June) was not regulated, so this part of monthly flow transferred to downstream areas. In the period, the MIF index changed more than TIF and VIF (Fig. 7b). In the last evaluation period (1990-2000), the added storage capacity of several dams (e.g., Mosul dam) enabled storage of flow during the high flow season and its release during the low flow season. This increased the potential for diverting flow by the Samara barrage and consequently the impact on Tigris flow at Baghdad increased to 'Severe' ('Post3' in Figs. 4f and 7b). 
Moving upstream along the Tigris main channel, the flow regime impact is lower, e.g., 'Incipient' and 'Low' at Mosul dam in northern Iraq and at Cizre in southern Turkey (last gauge in Turkey territory before entering Iraq) (Figs. 4e and 7b). Although Mosul dam has considerable capacity $\left(12.5 \mathrm{~km}^{3}\right)$, the impact at the dam site was classified as 'Incipient' due to the low reduction in magnitude of flow (MIF), with the major impact on flow characteristics being exerted on TIF and VIF (Fig. 7b).

The impacts on flow regime of other tributaries and headwaters, e.g., the Great Zab at Bekhme (Figs. 4i and 7b), Lesser Zab at Dokan dam (Iraq, 1961, $6.8 \mathrm{~km}^{3}$ ), Diyala at Derbendi Khan (Iraq, 1962, $3 \mathrm{~km}^{3}$ ) and Tigris at Diyarbakir (headwater in Turkey, Figs. 4c and 7b) were classified as 'Low' or 'Incipient' for the period 1990-2000. Although these dams were constructed for irrigation purposes, the irrigation demand is supplied by a diversion dam far away from the dam location, and hence the indices reflect minimal potential impact. According to our results, by 2000 the contribution of Turkey to flow regime alteration in the Tigris was low (Fig. 7b) and the greatest impact on flow regime was observed in the lower part of the Tigris in Iraqi territory, particularly below the Samara and Kut barrages.

To address the contribution of different countries to the natural flow of the Tigris and its change, the stations at Cizre $\left(38294 \mathrm{~km}^{2}\right)$, Baghdad $\left(134,000 \mathrm{~km}^{2}\right)$, and Kut $\left(166,200 \mathrm{~km}^{2}\right)$ were used to divide the Tigris basin into upper, middle, and lower sub-basins. Approximately $37 \%$ of the flow at Kut originates from the upper sub-basin (above Cizre in Turkish territory) and 55\% comes from the middle sub-basin (between Cizre and Baghdad, including western tributaries like Great and Lesser Zab which mainly originate in the Zagros Mountains), while the remaining $8 \%$ is the contribution of the rest of the basin. By 2000, major regulation was imposed on Tigris in Iraq by the construction of considerable storage and several diversion dams, but Turkey will continue to make a contribution on completing the GAP projects and certainly Ilisu dam (Torabi Haghighi et al. 2018).

\subsection{Monthly flow regime and its impact on Arvandroud and lower tributaries}

In Arvandroud, flow (RI) was 0.74, 0.54, 0.41, and 0.14 in 1941-1955, 1960-1970, 1974-1983, and 19901999, respectively, and the impact on flow was classified as 'Incipient', 'Moderate', Moderate', and 'Drastic', respectively (Fig. 7b). All three flow characteristics (magnitude, variability, and timing) in the Arvandroud river were altered and the river flow regime changed from a clearly seasonal regime in 1940-1955 to a uniform flow regime in 1990-1999 (Fig. 3a) indicating a strong impact of regulation. In the period 1941-1955, tributaries were modified only by two diversion dams in Iraq (Kut and Hindiya), and the impact was classified as 'Incipient' in this period due to low storage capacity of these dams. In the period 1960-1970, another diversion dam (Samarra barrage) was installed on the Tigris, and the RI decreased to 0.54. In the period 19741983, modification of the Euphrates continued with the construction of two storage dams in Turkey and Syria, and the RI was reduced to 0.41. The impact of the period 1990-1999 reflects the construction of many dams and hydropower facilities, which led to a 'Drastic' flow regime alteration in the Arvandroud. The flow change impacts in recent years have been even higher than in the period 1990-1999, as the tributaries have been modified by more dams, and the flow will change even more in future on completion of the planned projects in headwaters, particularly Ilisu dam on the Tigris in Turkey.

Above and below the confluence of the Tigris and Euphrates at Qurna, two major rivers (the Karkheh and Karun from Iran) join the Arvandroud river system. The Karkheh first discharges to Hooralazim wetland (area $900 \mathrm{~km}^{2}$ before shrinkage; (Fuladavand and Sayyad 2015), which is part of the Mesopotamian Marshlands. Annual water loss by the Mesopotamian Marshlands $\left(20000 \mathrm{~km}^{2}\right)$ is about $16 \mathrm{~km}^{3}$ (World Bank 2006). As the majority of Karkheh flow (mean annual flow 1971-2001 of $5.5 \mathrm{~km}^{3}$ at Hamidieh gauge) is consumed in the wetland, the Karkheh only makes a contribution to the Arvandroud river flow regime during years with high inflow to the wetland. Thus, the role of the Karkheh in the Arvandroud flow system is minor. Based on available data for the period 1990-2000, the river regime impact was classified as 'Low' (Figs. 4h and 7b), as the major dam on this river was installed in 2006 (after the last calculated period throughout this study). The Karun joins the Arvandroud just before it enters the Persian Gulf (Fig. 1). Most regulation practices on the Karun were imposed after 2000 and thus the flow regime impact analysis for the periods 1974-1983 and 1990-2000 showed a 'Low' impact for this river at Ahavaz city (Figs. 4h and 7b). 


\subsection{Spatio-temporal impact on the whole basin}

In terms of overall impact on the basin, the results clearly show that most of the headwater part of the basin is categorized in the 'Low' impact class, whereas low-lying areas and particularly the Arvandroud estuarine region have experienced an increasing rate of impact through the periods 1941-1955, 1960-1970, 1974-1984, and 1991-2000 (Fig. 8). It is worth mentioning that these periods have been selected based on major regulated practices in study area, for example in the first period (1941-1955), the flow regime affected by two diversion dams called Kut on Tigris and Hindiya, or in the second period we could see the impact of Samara barrage as a massive water diversion and also interbasin water transfer. In addition, an increase in the number of dams during different periods has extended the impact upstream in the basin. In the Euphrates, until 1970 the impact was restricted to inside Iraqi territory (Figs. 8a and 8b), while during the periods 1974-1984 and 1991-2000 the rate of impact increased in Iraq and also extended into Syria (Figs. 8c and 8d) and Turkey (Fig. 8d). In the Tigris, spatially the impact was still restricted inside Iraq by 2000, but the rate of impact was clearly increasing with a tendency to extend to upstream areas of the basin (Fig. 8). When GAP project construction, particularly Ilisu dam, on the Tigris is completed, the impact can be expected to extend to Turkey's territory (Torabi Haghighi et al. 2018).

In this work spatio-temporal flow regime impact was assessed by using River Impact method along these rivers which were missed during previous studies. For example, the hydrological impact of water resources development on the Mesopotamia Marshes was evaluated by using SWAT model (Jones et al., 2006) or evaluation of water resources of the Tigris river (Al-Ansari et al., 2018). The main drawback of this work is the period of analysis which is ended to 2000 as previously mentioned and indicated by others e.g. Kavvas et al. (2011). To overcome this data actualization issue, the remote sensing images were analyzed.

\subsection{Impact of Anthropogenic Activates on the Arvandroud Estuary}

Analysis of LULC in the Arvandroud estuary revealed the major consequences of river regulation and other anthropogenic activities (Fig. 9). Based on the comparison of LULC from 1972 to 2018 in the Arvandroud estuarine region (Fig. 1b), the main outcomes of anthropogenic activities are decreasing high density vegetation (32\%), growing area of bare land (17\%), and increasing low-density cover vegetation (16\%) (Figs. $9 \mathrm{a}$ and $9 \mathrm{~b})$. This indicated substantial LULC change in this area. Moreover, an increasing rate of sedimentation could be addressed in reduction of waterbody (1.26\%) and increasing the bare area which has affected navigation in the river. The extending sandy zone and shallow water area at the mouth of river due to the inflow reduction are causing difficulties for ships while passing through the main channel of Arvandroud.

This area was exposed to Iran-Iraq War (1980-1988). A sharp reduction (-3.53\% per year) in high density vegetation from 1985-1988 in comparison with long term reduction (-0.69\% per year) indicate the considerable impact of war (5.1 times of mean long-term impact) on high dense vegetation (Fig. 9). A sign of recovery $(+0.31 \%$ per year) is also visible in case of high dense vegetation, immediately after ending the conflict (1988-2003, Fig. 9). Reduction of high dense vegetation cover (-1.0\% per year) would be the results of river regime alteration and climate variability in this region (Fig. 9) after 2003.

For more detail, the NDVI values show negative trend after 2000 in all parts of inserted area (Fig. 10 c), and it was observed after a positive trend (or tendency) since 1984 (Fig. 10b). This negative trend would be due to flow regime change during 2000-2018, the period that we could not access to observed hydrological data. The variation of NDVI according to Z-score also indicates the negative value in recent years and it clearly shows the impact of flow regime particularly after 2010 (Fig. 10d).

Reduced freshwater flow has led to saltwater intrusion from the Persian Gulf, contributing to land and water salinization in the Arvandroud estuarine region. This is evident as expanding low-density vegetation cover along the river margin (Fig. 9). It is estimated that water salinization has led to death of 400,000 date palms in Abadan city, Iran (Islamic Republic News Agency - IRNA 2019). It is predicted that the number of dead palm trees will reach 2 million if salinization continues (Islamic Republic News Agency - IRNA 2015). Loss of agricultural land has had severe socioeconomic impacts on the region and these will only worsen in future if current water management practices continue. Moreover, the Hoor-Alazim wetland, in southwestern Iran, has shrunk from $900 \mathrm{~km}^{2}$ in 1992 to $300 \mathrm{~km}^{2}$ in 2008, mainly due to construction and impounding at Karkheh dam (Fuladavand and Sayyad 2015). 
Because of drying of the Hoor-Alazim and Iraqi marshlands, the incidence of dust storms in western cities of Iran has increased dramatically (Zarasvandi et al. 2011). During 2007-2009, about 120 dust storms occurred in urban areas in Khuzestan province, more than $50 \%$ of which reduced the maximum visibility to less than $1 \mathrm{~km}$ (Zarasvandi, 2011). During 2007-2009, about 120 dust storms occurred in urban areas in Khuzestan province, more than $50 \%$ of which reduced the maximum visibility to less than $1 \mathrm{~km}$ (Zarasvandi, 2011). These storms had major social impacts on the region, as schools, universities, and other organizations were shut down and daily activities were impaired.

The impact of flow regime alteration extends beyond the lowland region of riparian countries to the coast of the Persian Gulf, especially the Kuwait coastal zone, which is suffering from water quality and biological process degradation due to the reduction in freshwater flow from the Arvandroud. In our LULC analysis, we clearly demonstrate the impact of river regulation during the past 43 years and as novelty we quantify the intensity of the impact of Iran-Iraq war in comparison with river regulation impact.

\section{Conclusions}

In this study, a framework for assessing the impact of water construction on rivers and basins was applied to the Tigris-Euphrates basin. The results showed that upstream and downstream water developments in the Tigris-Euphrates water system have led to severe changes in the Arvandroud estuary. Construction of about $300 \mathrm{~km}^{3}$ of reservoirs on the water system since 1911 has had a drastic effect on the flow. Over time, the impact of flow regulation has extended along the basin from downstream to upstream. By 2000 (endpoint based on available data in this study), most of headwater area, particularly in Turkey and the eastern part of the Tigris basin in the Zagros Mountains, was still in the 'Low' impact class, while in middle part of the basin the impact increased during different periods. The greatest impact was observed after 1970, with increasing water competition between Iraq, Turkey, and Syria. This has led to severe changes in ecosystem services in the river, with catastrophic impacts on the socio-economic system. The impacts will intensify in future, as more dam construction projects are underway, and there may also be an influence of climate change. The main weakness of this work was the period of analysis which was ended to 2000 due to lack of data which was explained earlier. The resolving the shortage of updated data should be considered in future studies. In absence of observed flow data (2000-2018), the remote sensing data confirm change in estuarian zone clearly. The results of remote sensing analysis revealed that the war impact (based on the degradation of vegetation cover during 1985-1988) is 5.1 times of mean rate of change during 1972-2018. Quantifying the impact of war on natural system was the issue which is not studied in this region. Although land degradation in the estuary area is an important issue and visible from our results, but in the other hand the dams and hydropower have a crucial role in the economy of inhabitants and riverain country by providing water for irrigation or generating energy. Hydropolitic and water conflict on headwater tributaries of transboundary rivers lead to many problem and negative impacts on the flow regime in river lowlands. The Tigris-Euphrates water system is an exemplary case of transboundary rivers that has drastically suffered from the impacts of river regulation and water management practices. The challenging situation arises from the conflicts and non-cooperative management of the water resources by the riparian countries. Downstream marshes and wetlands gave many invaluable ecosystem services to local inhabitants and provided a thriving habitat for fauna and flora for centuries. Hydropolitic and water conflict between riparian countries have placed these invaluable aqua-ecosystems, estuarine zone and their dependent anthroposphere at a "mercy position" for minimum environmental flow.

\section{Conflict of interest}

The authors declare no conflict of interest.

\section{References}

Akhter M (2015) The hydropolitical Cold War: The Indus Waters Treaty and state formation in Pakistan. Political Geography 46: 65-75.

Al Bomola AH (2011) Temporal and Spatial Changes in Water Quality of the Euphrates River - Iraq. 
Al-Ansari, N.A., Sherwany, G. and Knutsson, S. (2014) Expected Future of Water Resources within TigrisEuphrates Rivers Basin, Iraq. Jwarp 6: 421-432.

Al-Mutairi N, Abahussain A and El-Battay A (2014) Spatial and temporal characterizations of water quality in Kuwait Bay. Marine Pollution Bulletin 83(1): 127-131.

Al-Yamani F (2008) Importance of the freshwater influx from the Shatt-Al-Arab River on the Gulf marine environment. In: Abuzinada AH, Barth HJ, Krupp F, Böer B and Al Abdessalaam TZ (eds) Protecting the Gulf's Marine Ecosystems from Pollution. Basel: Birkhäuser, 207-222.

Ashraf FB, Haghighi AT, Riml J, Alfredsen K, Koskela JJ, Kløve B, et al. (2018) Changes in short term river flow regulation and hydropeaking in Nordic rivers. Scientific Reports 8(1).

Biedler M (2004) Hydropolitics of the Tigris - Euphrates River basin with implication for European union . Ceris Research Papers $\mathrm{N}^{\circ} 1$.

Cao H, Amiraslani F, Liu J and Zhou N (2015) Identification of dust storm source areas in West Asia using multiple environmental datasets. Science of the Total Environment 502: 224-235.

Eng K, Wolock DM and Carlisle DM (2013) River flow changes related to land and water management practices across the conterminous United States. Science of the Total Environment 463-464: 414-422.

Etemad Shahidi AF, Saburi AA and Parsa J (2011) Control of Salinity Intrusion in Arvand Estuary Under Different Hydrological Conditions. $\operatorname{Ir}-\operatorname{Wrr} 2$ : 50-60.

FAO (2009) Euphrates-Tigris Basin.

Fazel N, Torabi Haghighi A and Kløve B (2017) Analysis of land use and climate change impacts by comparing river flow records for headwaters and lowland reaches. Global and Planetary Change 158: 4756.

Fuladavand S and Sayyad GA (2015) Samira The Impact of Karkheh Dam Construction on Reducing the Extent of Wetlands of Hoor-Alazim. . Journal of Water Resources and Ocean Science 2: 33-38.

Ghandehari A, Shadzad S, Abrishamchi A and Tajrishi M (2007) The Impacts of Upstream Activities on Water Quality of Arvandroud and Karun Rivers.

Hamel S, Garel M, Festa-Bianchet M, Gaillard J- and Côté SD (2009) Spring Normalized Difference Vegetation Index (NDVI) predicts annual variation in timing of peak faecal crude protein in mountain ungulates. Journal of Applied Ecology 46(3): 582-589.

Hamidi M, Kavianpour MR and Shao Y (2013) Synoptic analysis of dust storms in the Middle East. AsiaPacific Journal of Atmospheric Sciences 49(3): 279-286.

Hekmatzadeh AA, Torabi Haghighi A, Hosseini Guyomi K, Amiri SM and Kløve B (2020) The effects of extremes and temporal scale on multifractal properties of river flow time series. River Research and Applications 36(1): 171-182.

Hirsch P (2016) The shifting regional geopolitics of Mekong dams. Political Geography 51: 63-74.

Islamic Republic News Agency - IRNA (2019) Http://Www.Irna.Ir/Khuzestan/Fa/News/82713186. 
Islamic Republic News Agency - IRNA (2015) Http://Www.Irna.Ir/Khuzestan/Fa/News/81682759.

Kavvas ML, Chen ZQ, Anderson ML, Ohara N, Yoon JY and Xiang F (2011) A Study of Water Balances Over the Tigris-Euphrates Watershed.

Keramat A, Marivani B and Samsami M (2011) Climatic change, drought and dust crisis in Iran. World Academy of Science, Engineering and Technology 81: 10-13.

Lotze HK, Lenihan HS, Bourque BJ, Bradbury RH, Cooke RG, Kay MC, et al. (2006) Depletion degradation, and recovery potential of estuaries and coastal seas. Science 312(5781): 1806-1809.

Mustonen K-, Mykrä H, Marttila H, Haghighi AT, Kløve B, Aroviita J, et al. (2016) Defining the natural flow regimes of boreal rivers: Relationship with benthic macroinvertebrate communities. Freshwater Science 35(2): 559-572.

Nilsson C, Reidy CA, Dynesius M and Revenga C (2005) Fragmentation and flow regulation of the world's large river systems. Science 308(5720): 405-408.

Partow H (2001) The Mesopotamian Marshlands: Demise of an Ecosystem. Nairobi (Kenya): Division of Early Warning and Assessment, United Nations Environment Programme. Unep UNEP/DEWA/ TR.01-3.

Patiris DL, Tsabaris C, Anagnostou CL, Androulakaki EG, Pappa FK, Eleftheriou G, et al. (2016) Activity concentration and spatial distribution of radionuclides in marine sediments close to the estuary of Shatt alArab/Arvand Rud River, the Gulf. Journal of Environmental Radioactivity 157: 1-15.

Peel MC, Finlayson BL and McMahon TA (2007) Updated world map of the Köppen-Geiger climate classification. Hydrology and Earth System Sciences 11(5): 1633-1644.

Petersen-Perlman JD (2016) Water Conflict/Cooperation Case Study: Zambezi River Basin Anonymous Reference Module in Earth Systems and Environmental Sciences. : Elsevier.

Pirnia A, Darabi H, Choubin B, Omidvar E, Onyutha C and Haghighi AT (2019) Contribution of climatic variability and human activities to stream flow changes in the Haraz River basin, northern Iran. Journal of Hydro-Environment Research 25: 12-24.

Radinger J, Alcaraz-Hernández JD and García-Berthou E (2018) Environmental and spatial correlates of hydrologic alteration in a large Mediterranean river catchment. Science of the Total Environment 639: 11381147.

Richardson CJ and Hussain NA (2006) Restoring the garden of eden: An ecological assessment of the marshes of Iraq. BioScience 56: 477-489.

Rowley G (1993) Multinational and National Competition for Water in the Middle East: Towards the Deepening Crisis. Journal of Environmental Management 39(3): 187-197.

Saleh DK (2010) Stream Gage Descriptions and Streamflow Statistics for Sites in the Tigris River and Euphrates River Basins, Iraq.

Sneddon C and Fox C (2006) Rethinking transboundary waters: A critical hydropolitics of the Mekong basin. Political Geography 25(2): 181-202. 
Sofer A (1999) Rivers of Fire: The Conflict Over Water in the Middle East. USA: Lanham, Md.: Rowman \& Littlefield Publishers.

Torabi Haghighi A, Menberu MW, Akanegbu J, Darabi H and Klove B (2018) Analysis of peatland changes by remote sensing after drainage for peat extraction. Land Degradation \& Development 29(10): 3479-3488.

Torabi Haghighi A, Sönmez MA, Fazel N, Yilmaz N and Björn K (2018) Tigris Flow Regime and Possible Impact of Ilisu Dam on the Monthly Flow Regime.

Torabi Haghighi A and Kløve B (2017) Design of environmental flow regimes to maintain lakes and wetlands in regions with high seasonal irrigation demand. Ecological Engineering 100: 120-129.

Torabi Haghighi A and Kløve B (2013) Development of a general river regime index (RRI) for intra-annual flow variation based on the unit river concept and flow variation end-points. Journal of Hydrology 503: 169177.

Torabi Haghighi A, Darabi H, Shahedi K, Solaimani K and Kløve B (2020) A Scenario-Based Approach for Assessing the Hydrological Impacts of Land Use and Climate Change in the Marboreh Watershed, Iran. Environmental Modeling and Assessment 25: 41-57.

Torabi Haghighi A, Marttila H and Kløve B (2014) Development of a new index to assess river regime impacts after dam construction. Global and Planetary Change 122(0): 186-196.

UNESCO (2013) http://Webworld.Unesco.Org/Water/Ihp/Db/Shiklomanov/part\%274/ASIA.

UN-ESCWA, BGR (United Nations Economic and Social Commission for Western Asia and Bundesanstalt für Geowissenschaften und Rohstoffe) (2013) Inventory of Shared Water Resources in Western Asia. Beirut: United Nations.

World Bank (2006) Iraq: Country Water Resource Assistance Strategy: Addressing Major Threats to People's Livelihoods.

Yaraghi N, Ronkanen A, Darabi H, Kløve B and Torabi Haghighi A (2019) Impact of managed aquifer recharge structure on river flow regimes in arid and semi-arid climates. Science of the Total Environment 675: 429-438.

Yetim M (2002) Governing International Common Pool Resources: the international watercourses of the Middle East. Water Policy 4(4): 305-321.

Yilmaz M (2003) The War that Never Happened: The Sharing of Euphrates - Tigris Rivers' Water between Turkey, Syria and Iraq.

Zahed F, Etemad-Shahidi A and Jabbaria E (2008) Modeling of salinity intrusion under different hydrological condition in Arvand River Estuary. Canadian J. of Civil Engineering 35: 1476-1480.

Zarasvandi A, Carranza EJM, Moore F and Rastmanesh F (2011) Spatio-temporal occurrences and mineralogical-geochemical characteristics of airborne dusts in Khuzestan Province (southwestern Iran). Journal of Geochemical Exploration 111(3): 138-151. 
Table 1: River flow gauging stations in the study area

\begin{tabular}{|c|c|c|c|c|c|}
\hline River & Station & Country & Latitude & Longitude & Area $\left(\mathrm{km}^{2}\right)$ \\
\hline Euphrates & Keban & Turkey & 38.82 & 38.77 & 63875 \\
\hline Euphrates & Tabaqah & Syria & 35.86 & 38.58 & 121000 \\
\hline Euphrates & Deir Ez-Zor & Syria & 35.26 & 40.28 & 150000 \\
\hline Euphrates & Hit & Iraq & 33.61 & 42.84 & 264100 \\
\hline Euphrates & Hindiya Barrage & Iraq & 32.72 & 44.27 & 274100 \\
\hline Karasu (H.W. Eu.) & Muş-Bingöl & Turkey & 38.78 & 41.50 & 2098.4 \\
\hline Murat (H.W. Eu.) & Elazığ-Palu & Turkey & 38.70 & 39.95 & 25447.2 \\
\hline Diyala (T. Ti.) & Gauge & Iraq & 35.10 & 45.70 & 29700 \\
\hline Diyala (T. Ti.) & Derbendi-Khan & Iraq & 35.13 & 45.75 & 17800 \\
\hline Adhaim (T. Ti.) & Injana & Iraq & 34.5 & 44.52 & 9840 \\
\hline Lesser Zab (T. Ti.) & Dokan & Iraq & 35.95 & 44.95 & 11700 \\
\hline Greater Zab (T. Ti.) & Eski Kelek & Iraq & 36.27 & 43.65 & 20500 \\
\hline Khazir (T. Ti.) & Manquba & Iraq & 36.3 & 43.55 & 2900 \\
\hline Tigris (H.W.) & Cizre & Turkey & 37.33 & 42.19 & 38294 \\
\hline Tigris (H.W.) & Diyarbakir & Turkey & 37.86 & 40.24 & 6106 \\
\hline Tigris & Mosul & Iraq & 36.62 & 42.82 & 56000 \\
\hline Tigris & Beiji & Iraq & 34.93 & 43.49 & 107600 \\
\hline Tigris & Baghdad & Iraq & 33.41 & 44.34 & 134000 \\
\hline Tigris & Kut & Iraq & 32.72 & 45.79 & 166200 \\
\hline Gharraf & Kut & Iraq & 32.53 & 45.79 & N.A \\
\hline Karkheh & Hamidieh & Iran & 31.5 & 48.43 & 50600 \\
\hline Karun & Ahvaz & Iran & 31.32 & 48.67 & 60769 \\
\hline
\end{tabular}



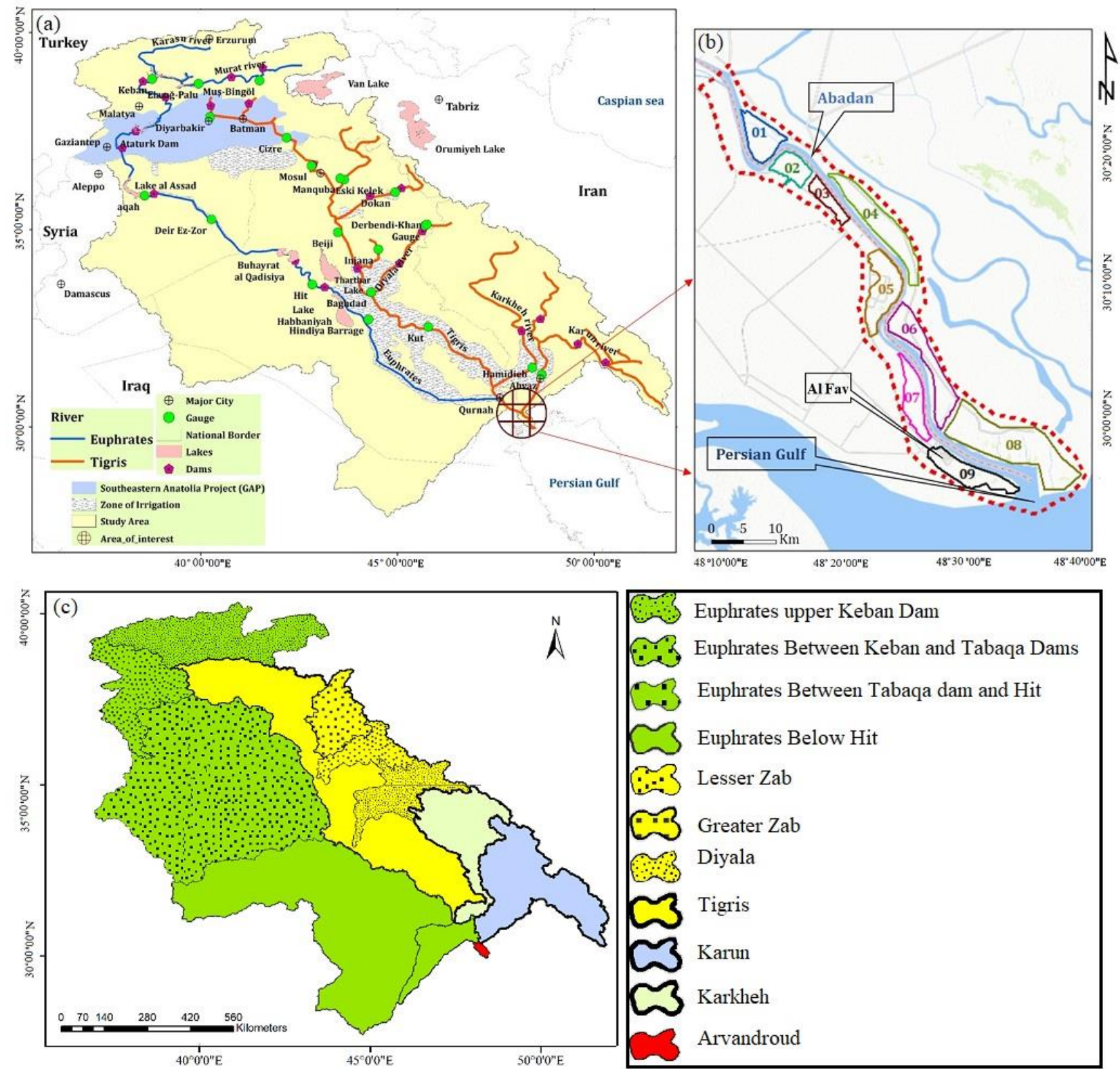

Fig. 1: Map of the study area showing a: major rivers and their tributaries, major cities, large dams, and gauging stations and b) Arvandroud estuary 


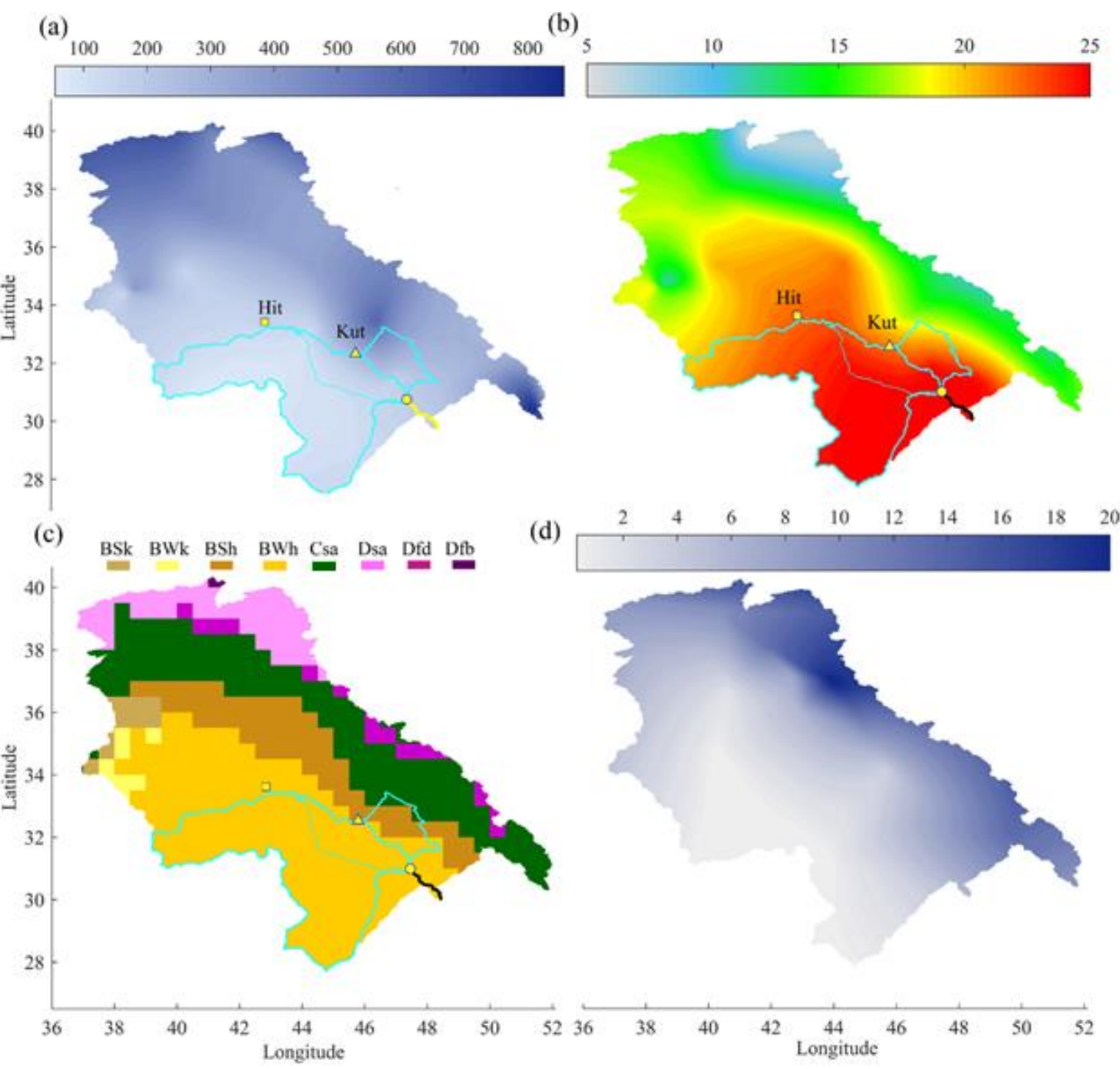

Fig. 2: Hydro-climatology of the Arvandroud basin: a) Annual precipitation (mm), b) mean annual temperature $\left.\left({ }^{\circ} \mathrm{C}\right), \mathrm{c}\right)$ climate classification based on Köppen Method, and d) specific discharge (mm $\mathrm{km}^{-2}$ ) 


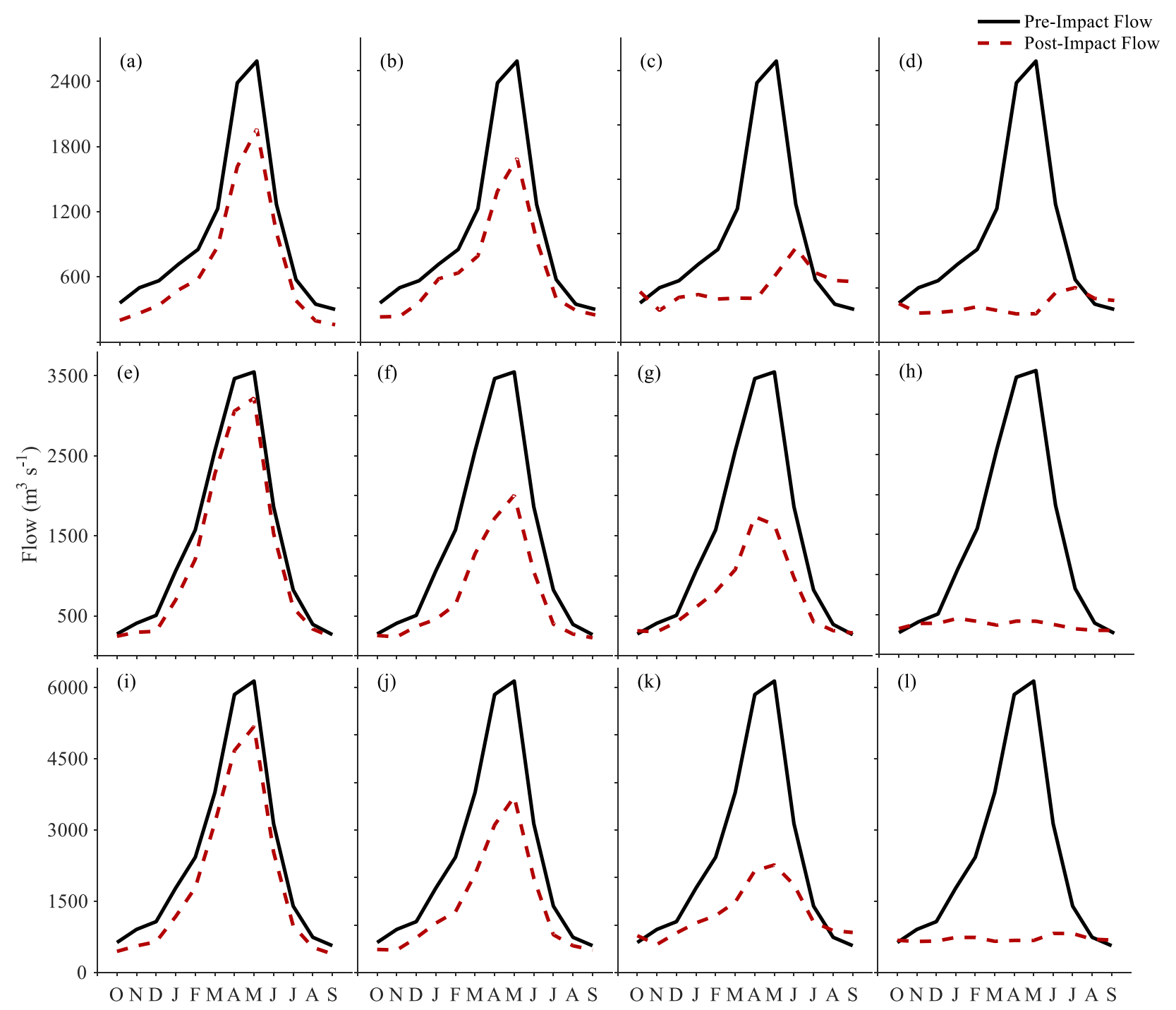

Fig. 3: River flow in the lower part of the basin, including pre- and post-impact flow of the Euphrates river at Hit station ( $\mathrm{a}, \mathrm{b}, \mathrm{c}$, and d), the Tigris river at Kut station (e, f, g, and h) and the Arvandroud river at the confluence (i, k, 1, and m), during 1941-55, 1960-70, 1974-84, and 1990-2000, respectively, where O-...-S means October - .... -September 


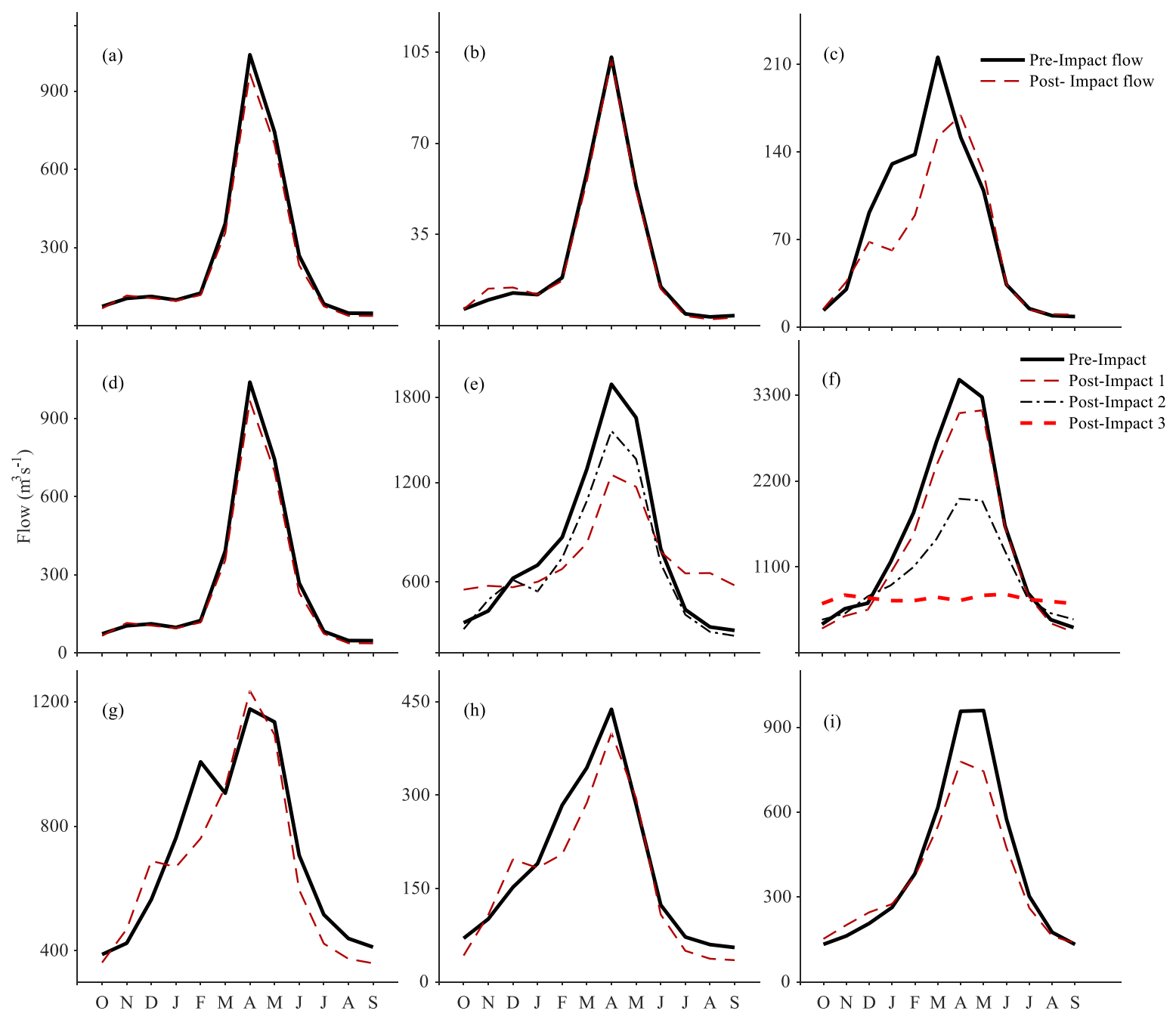

Fig. 4: River flow in headwaters, middle basin area, and tributaries to the basin. a, b) Murat and Karasu, headwaters of the Euphrates river (Pre: 1969-1980, Post: 1991-2006), c-f) Tigris river at Diyarbakir, Cizre (Pre: 1969-1980, Post: 1991-2006), Mosul (Pre: 1969-1980, Post: 1991-2006), and Baghdad (Pre: flow at Beiji 1940-1955, post1, post2 and post3: flow at Baghdad 1940-1955, 1961-1980 and 1983-2000), g, h) the Karun and Karkheh rivers at Ahvaz and Hamidieh (Pre: 1974-1984, Post: 19902000), and i) Great Zab river at Bekhem (1940-78 and 1979-2004), where O-...-S means October - .... -September. 


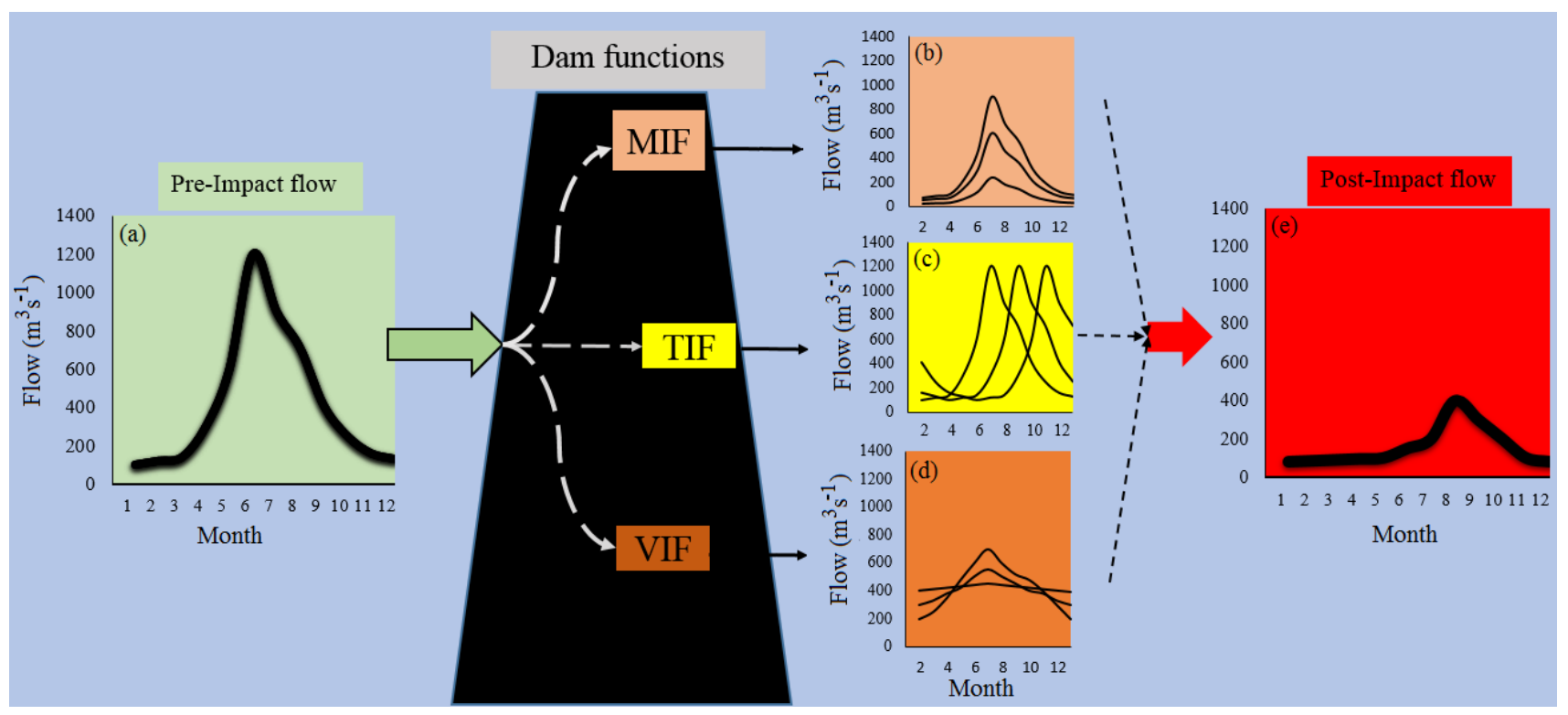

Fig. 5: Change in intra-annual flow regime due to dam operation: a) intra-annual flow before dam operation (pre-impact), b) change in magnitude of flow impact factor, c) intra-annual flow variability factor (VIF), d) timing impact factor and e) intra-annual flow after dam operation (post-impact).

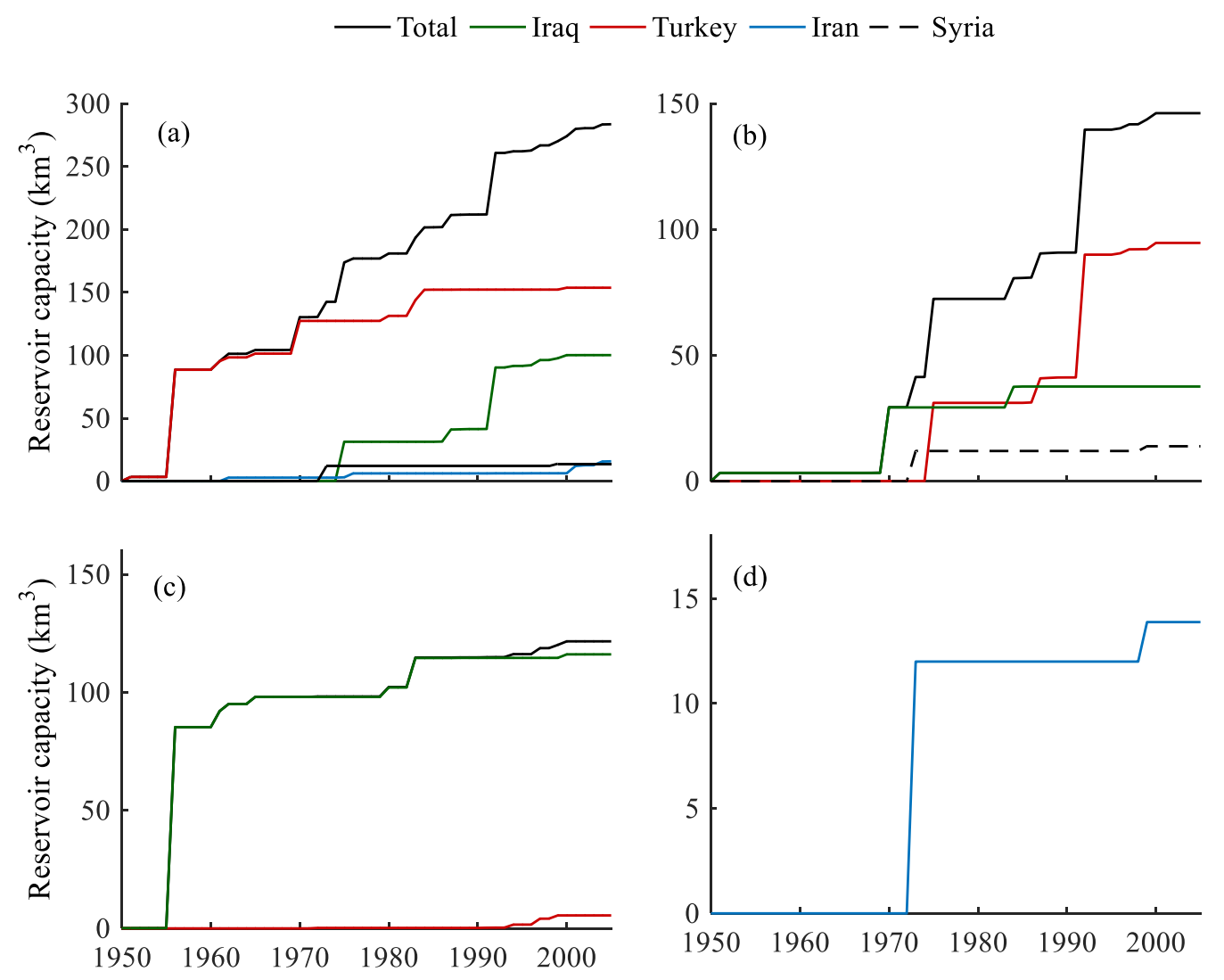

Fig. 6: Cumulative reservoir capacity in riparian countries in the main river and tributaries in: a) the entire basin, b) the Euphrates, c) the Tigris, and d) the Karkheh and Karun (Source of data: FAO). 

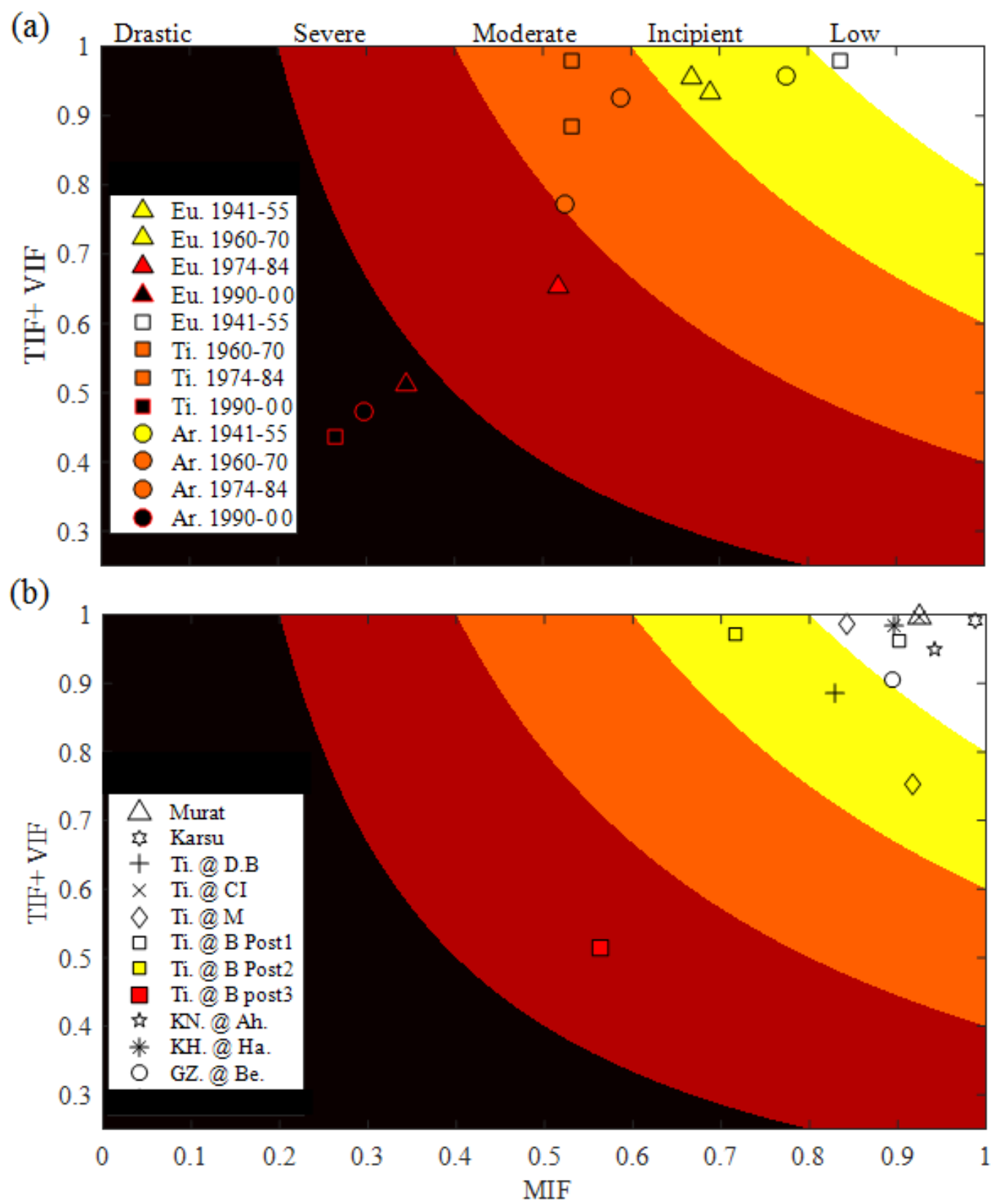

Fig. 7: Flow regime impact in: a) lower part of the basin, Eu: Euphrates at Hit, Ti: Tigris at Kut, Ar: Arvandroud, and b) headwaters, middle, and tributaries of the basin: Murat and Karasu headwaters of Euphrates, Ti.: Tigris at Diyarbakir (DB), Cizre (CI), Mosul (M), and Baghdad (B), Karun (KN) at Ahvaz (Ah), Karkheh (KH), and Hamidieh (Ha), and Great Zab (GZ) at Bekhem (Be). 


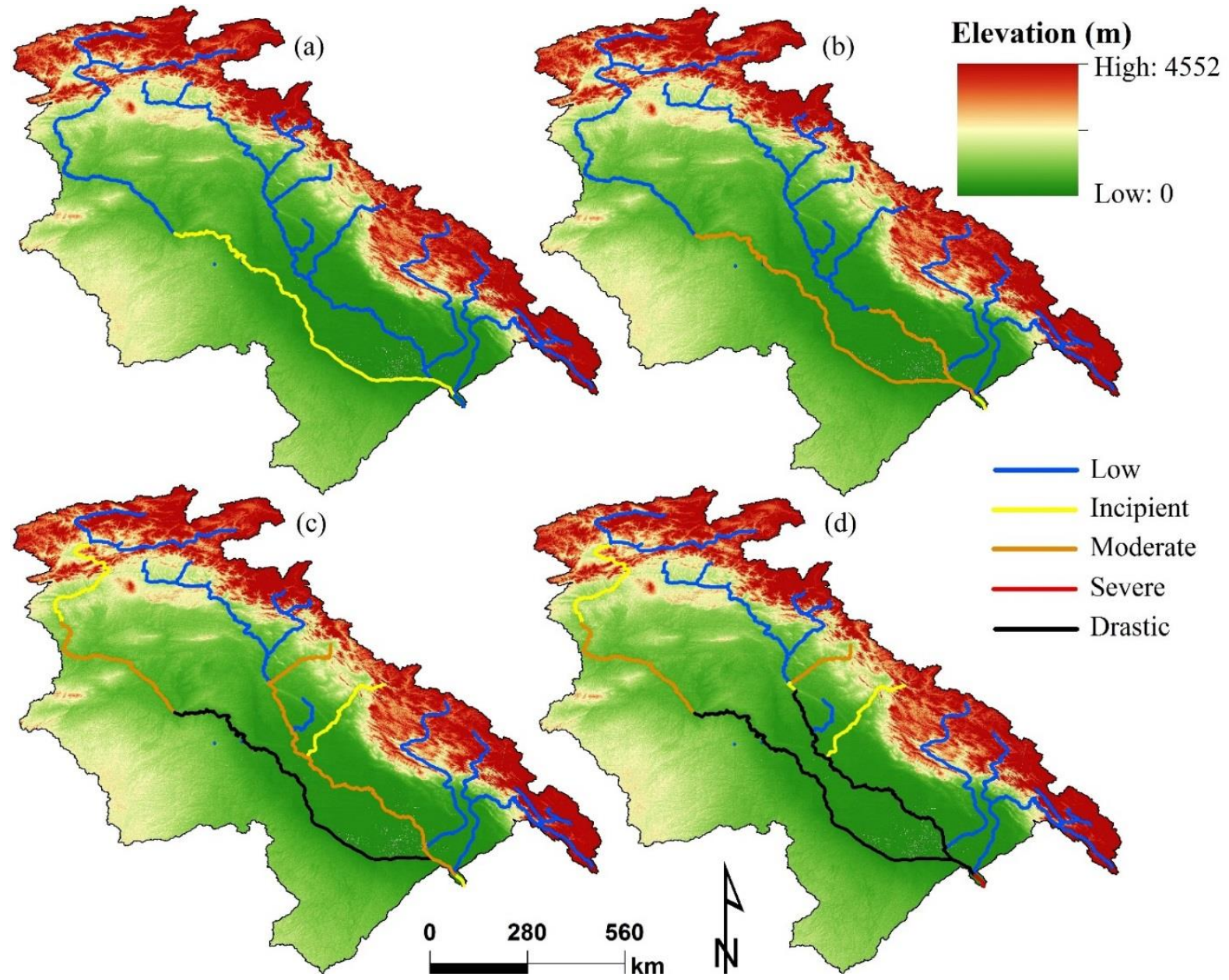

Fig. 8: Spatio-temporal flow regime impact on the Arvandroud river and upstream tributaries, based on river impact (RI) index in: a) 1941-1955, b) 1960-1970 c) 1970-1984, and d) 1990-2000. 
(a)
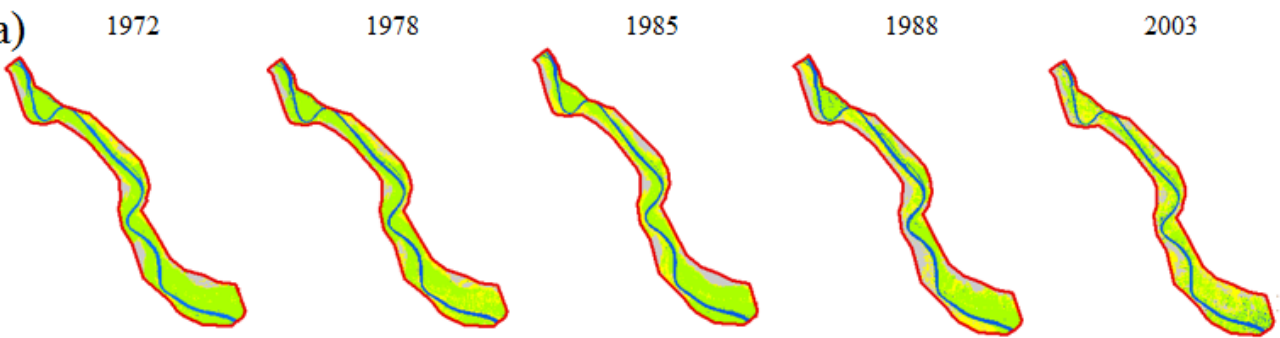

2018

(b)

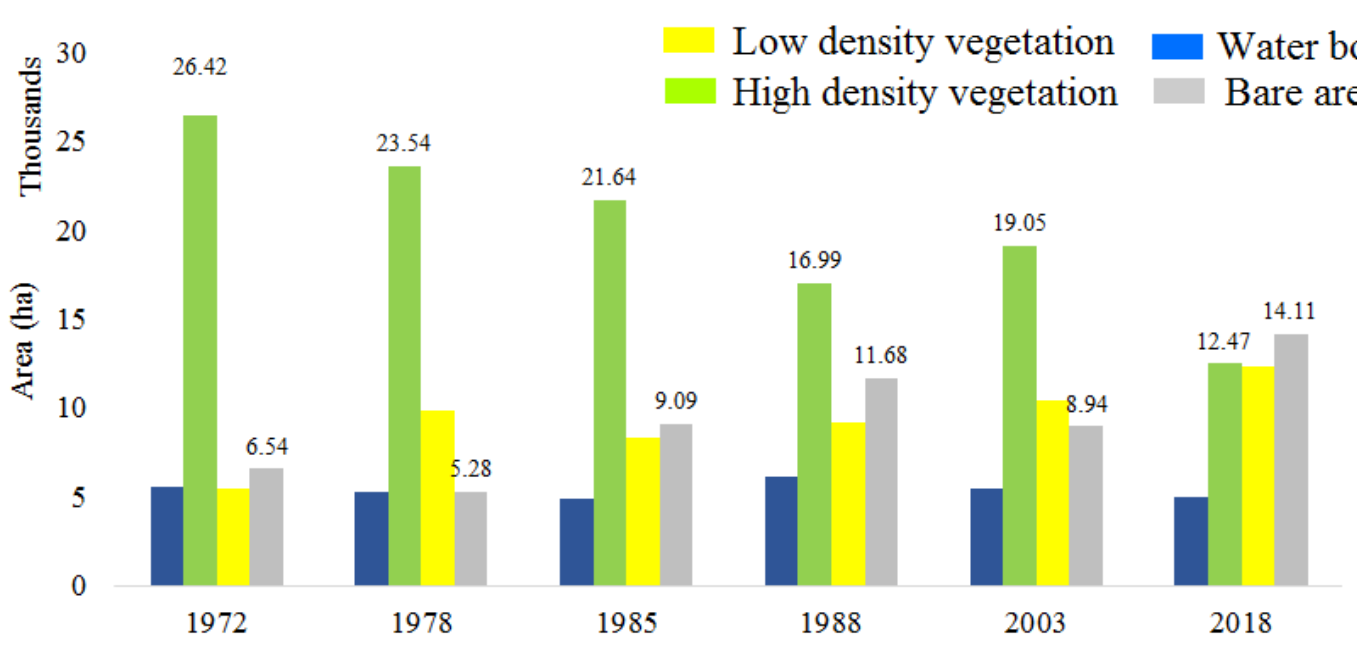

Fig. 9: Land use and land cover (LC) change (1972, 1978, 1985, 1988, 2003 and 2018) in the Arvandroud estuarine region determined using the LC index. 
(a)
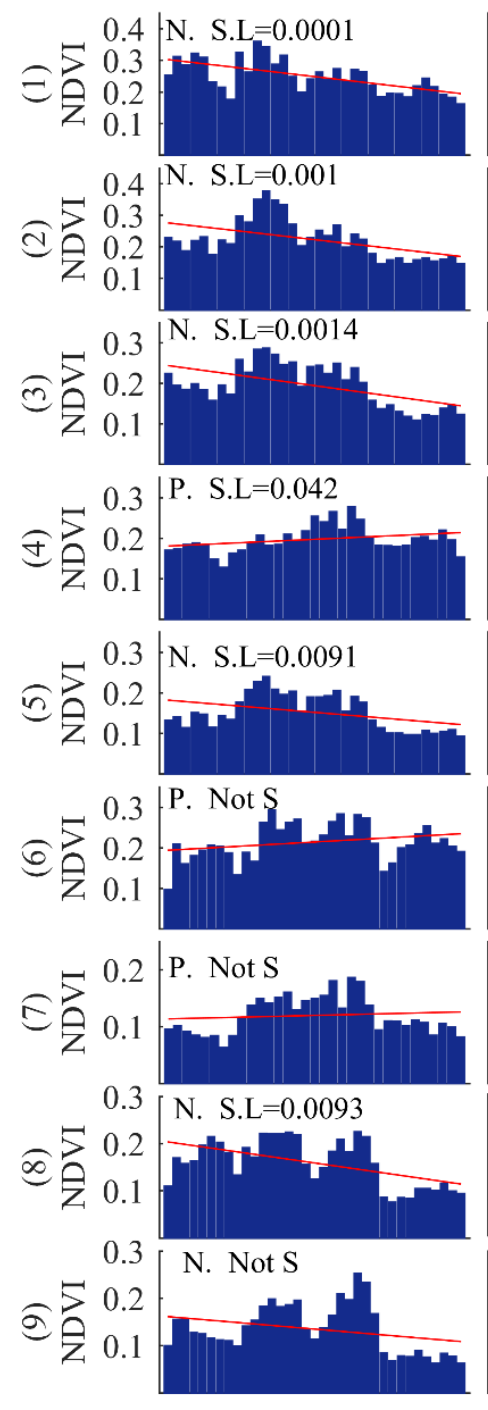

1984199520052015 (b)

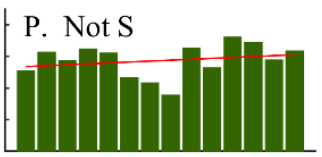

P. $S . L=0.012$

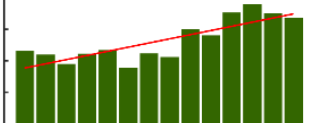

P. Not S

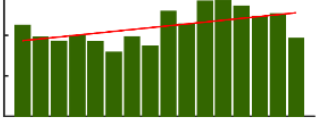

P. $\mathrm{S} . \mathrm{L}=0.0015$
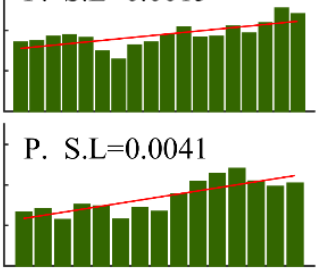

P. Not S

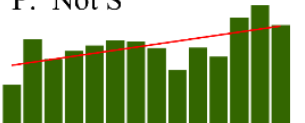

P. S.L $=0.029$

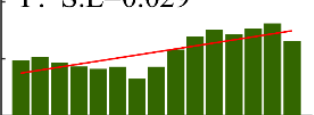

P. S.L $=0.0046$

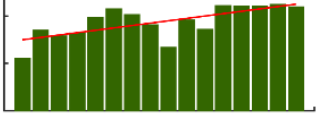

P. S.L $=0.038$

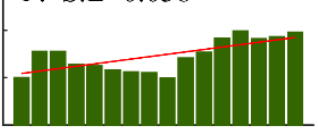

1992 (c)

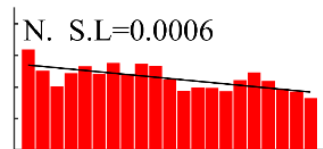

N. $S . L=0.0002$

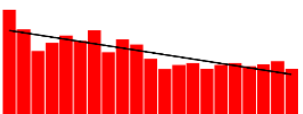

N. S.L $=0.0005$

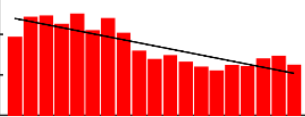

N. $S . L=0.034$

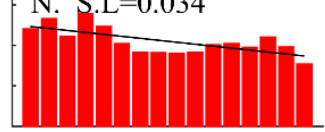

N. $S . L=0.0002$

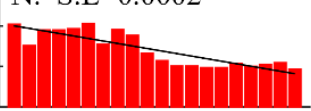

N. $S . L=0.048$

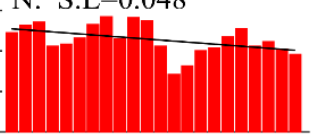

N. $S . L=0.001$

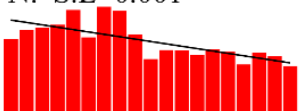

N. $S . L=0.012$
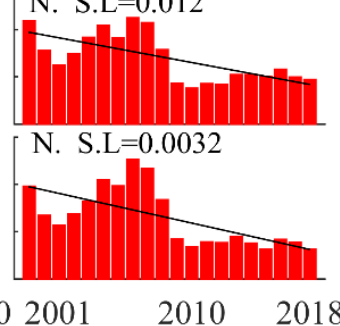

(d)
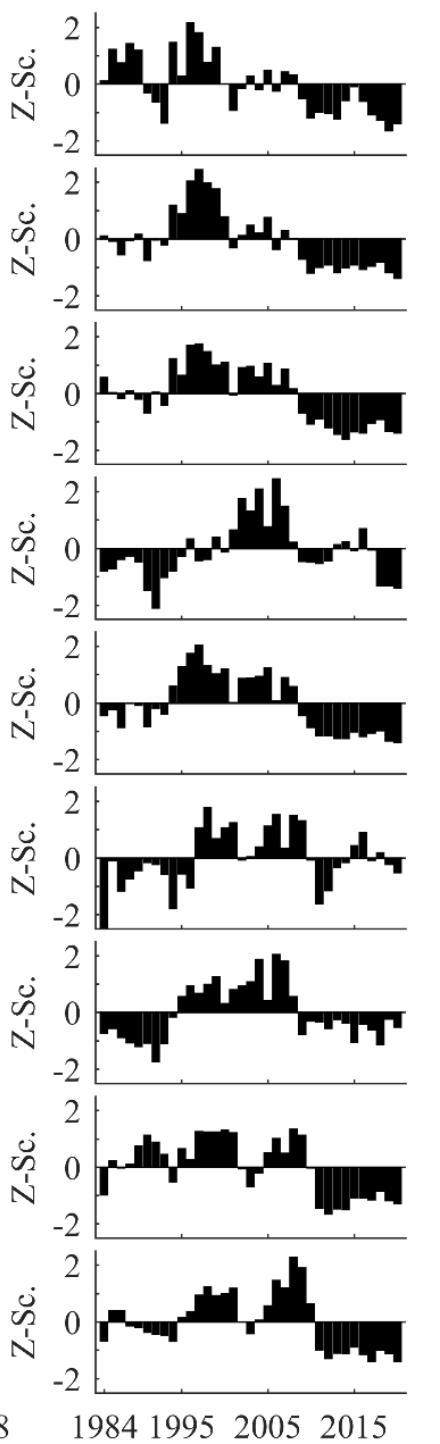

Fig. 10: Change in vegetation cover (1984 - 2018) in different parts of Arvandroud estuarine region (parts 1-9 according to Fig. 1) determined using normalized difference vegetation index (NDVI), a, b, c: NDVI variation in 1984-2018, 1984-2000 and 2000-2018 respectively and d: Z-score for NDVI value. P. and N. indicate the Positive or Negative trend or tendency. S.L: significance level and Not S: Not significant trend 


\section{SUPPORTING INFORMATION FOR:}

The impact of river regulation in the Tigris and Euphrates on the Arvandroud Estuary 


\section{Contents of this file}

Table S1

Table S2 
Table S1. Chronology of major event in studied area (FAO, AQUASTAT 2009)

\begin{tabular}{|c|c|c|c|}
\hline Year & Plans/Projects/Treaties/Conflicts & Countries involved & Main aspects \\
\hline 1914 & Al Hindiya dam on the Euphrates & Iraq & For flood control and irrigation purposes. \\
\hline 1920 & $\begin{array}{l}\text { Treaty regarding utilization of the waters } \\
\text { of the Euphrates and Tigris rivers }\end{array}$ & France and Great Britain & \\
\hline 1930 & Turco-French Protocol & Turkey and France & $\begin{array}{l}\text { Coordinates any plans to use the waters of the } \\
\text { Euphrates. }\end{array}$ \\
\hline 1946 & $\begin{array}{l}\text { Treaty of friendship and good neighborly } \\
\text { relations }\end{array}$ & Turkey and Iraq & $\begin{array}{l}\text { Extended the principals of mutual cooperation over } \\
\text { water development in both rivers. Sharing of related } \\
\text { data. }\end{array}$ \\
\hline 1951 & Ramadi Habbaniya dam on the Euphrates & Iraq & For flood control and irrigation purposes \\
\hline $1960 \mathrm{~s}$ & Start of construction of the 'Third River' & Iraq & $\begin{array}{l}565 \mathrm{~km} \text { canal between the Euphrates and the Tigris } \\
\text { rivers (completed in 1992). }\end{array}$ \\
\hline $1970 \mathrm{~s}$ & Construction of several canals & Iraq & $\begin{array}{l}\text { Linking lake Thartar to the Euphrates, and connecting } \\
\text { the lake with the Tigris. }\end{array}$ \\
\hline 1973 & The Kevan dam & Turkey & $\begin{array}{l}\text { First dam on the Euphrates for Turkey. Construction } \\
\text { started in 1960s. for hydropower purposes. }\end{array}$ \\
\hline 1973 & The Tabqa dam & Syria (with the help of USSR) & $\begin{array}{l}\text { First dam on the Euphrates for Syria to meet water and } \\
\text { energy needs. }\end{array}$ \\
\hline 1975 & Filling of the Tabqa dam conflict & $\begin{array}{l}\text { Syria and Iraq (Saudi Arabia and } \\
\text { possibly USSR mediated) }\end{array}$ & $\begin{array}{l}\text { Major source of conflict between Syrians and Iraqis } \\
\text { addressed. Finally the Syria released more water from } \\
\text { the dam to Iraq. }\end{array}$ \\
\hline 1976 & $\begin{array}{l}\text { Release of } 350 \mathrm{~m}^{3} / \mathrm{s} \text { from the Euphrates } \\
\text { downstream }\end{array}$ & Turkey & $\begin{array}{l}\text { Prevented tension between Syria and Iraq, regarding } \\
\text { the filling of the Tabqa dam. }\end{array}$ \\
\hline 1977 & Southeastern Anatolia Project (GAP) & Turkey & $\begin{array}{l}\text { Turkey announced plans for GAP, which included } 22 \\
\text { dams and } 19 \text { hydropower installations on the } \\
\text { Euphrates-Tigris. }\end{array}$ \\
\hline 1983 & $\begin{array}{l}\text { Establishment of joint technical committee } \\
\text { for regional waters }\end{array}$ & Turkey, Iraq, and Syria & $\begin{array}{l}\text { Dealing with water issues between the basin riparian } \\
\text { countries, to ensure principals of consultation and } \\
\text { notification as required by international law. This } \\
\text { group disintegrated after } 1993 \text { without any progress } \\
\text { having been made. }\end{array}$ \\
\hline 1984 & Turkey proposes a 'Three staged-plan' & Turkey (indirectly Syria and Iraq) & $\begin{array}{l}\text { For optimal, equitable and reasonable utilization of the } \\
\text { transboundary watercourses of the Euphrates-Tigris } \\
\text { basin. Confirms to the principle of equitable } \\
\text { utilization. }\end{array}$ \\
\hline 1986 & The Bath dam & Syria & $\begin{array}{l}\text { Second dam on the Euphrates for the Syria. Small- } \\
\text { scale electric generation and small amount of water for } \\
\text { irrigation. }\end{array}$ \\
\hline 1987 & $\begin{array}{l}\text { Informal agreement guaranteed } 500 \mathrm{~m}^{3} / \mathrm{s} \\
\text { of the Euphrates from Turkey to the Syria }\end{array}$ & Turkey and Syria & $\begin{array}{l}\text { The Syria has accused Turkey of violating this } \\
\text { agreement a number of times. }\end{array}$ \\
\hline 1988 & The Karakaya dam & Turkey & $\begin{array}{l}\text { Second dam on the Euphrates for Turkey. First dam } \\
\text { built under the GAP. For production of hydropower. }\end{array}$ \\
\hline 1990 & $\begin{array}{l}\text { Agreement between Syria and Iraq to share } \\
\text { the Euphrates water }\end{array}$ & Syria and Iraq & $\begin{array}{l}\text { The Syria agrees to share the Euphrates' water with } \\
\text { Iraq on a } 58 \% \text { (Iraq) and } 42 \% \text { (Syria) basis. } \\
\text { Corresponds to a flow of } 9 \mathrm{~km}^{3} / \text { year. }\end{array}$ \\
\hline 1992 & Completion of the Ataturk dam & Turkey & $\begin{array}{l}\text { Third dam on the Euphrates for Turkey, the most } \\
\text { important one under the GAP project. For irrigation } \\
\text { and hydropower. The filling of the dam, shutting of } \\
\text { the river flow for a month, causes conflict with } \\
\text { Syrians and Iraqis. }\end{array}$ \\
\hline 2001 & Joint Communique & $\begin{array}{l}\text { GOLD (Syria), and GAP-RDA } \\
\text { (Turkey) }\end{array}$ & $\begin{array}{l}\text { Supporting training, technology exchange, study } \\
\text { missions, and joint projects. }\end{array}$ \\
\hline 2002 & $\begin{array}{l}\text { Bilateral agreement concerning the } \\
\text { installation of a Syrian pump station on the } \\
\text { Tigris river }\end{array}$ & Syria and Iraq & For irrigation purposes. \\
\hline 2008 & $\begin{array}{l}\text { Cooperation on water issues by } \\
\text { establishing a water institute }\end{array}$ & Turkey, Syria, and Iraq & $\begin{array}{l}18 \text { water experts from each country to work toward } \\
\text { the resolution of water-related problems. }\end{array}$ \\
\hline
\end{tabular}


Table S2. Large dams in the studied area (FAO, AQUASTAT 2009)

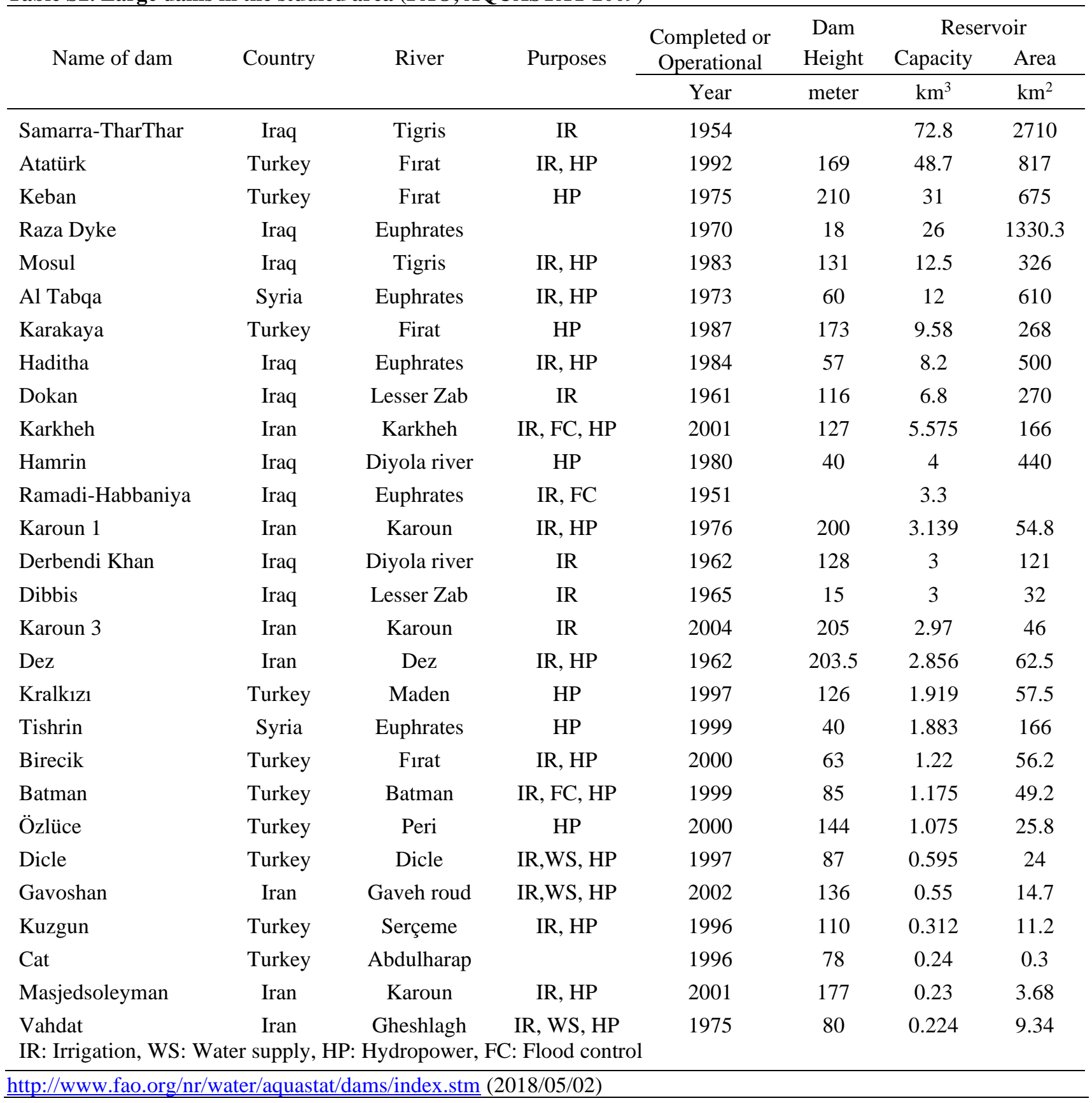


